\title{
Oceanographic habitat and the coral microbiomes of urban- impacted reefs
}

\author{
Stephanie M Rosales ${ }^{1,2}$, Christopher Sinigalliano $^{2}$, Maribeth Gidley ${ }^{1,2}$, Paul R Jones ${ }^{1,2}$, Lewis J Gramer ${ }^{\text {Corresp. } 1,2}$ \\ ${ }^{1}$ Cooperative Institute for Marine and Atmospheric Studies, University of Miami, Miami, FL, United States \\ 2 Atlantic Oceanographic and Meteorological Laboratory, National Oceanographic and Atmospheric Administration, Miami, FL, United States \\ Corresponding Author: Lewis J Gramer \\ Email address: lew.gramer@noaa.gov
}

Coral reefs are in decline worldwide. In response to this habitat loss, there are efforts to grow, outplant, and restore corals in many regions. The physical oceanographic habitat of corals - such as sea temperature, waves, ocean currents, and available light - is spatially heterogeneous. We therefore hypothesize that outplant location may affect microbiomes, and ultimately, coral health and restoration success. We evaluated the influence of the physical oceanographic habitat on microbes in wild Porites astreoides and Siderastrea siderea. Tissue samples were collected at four Florida reefs in March, June, and September of 2015. We estimated oceanographic conditions from moored instruments, diver observations, remote sensing data, and numerical models. We analyzed microbiomes using amplicon 16S rRNA high-throughput sequencing data. We found microbial alphadiversity negatively correlated with in situ sea temperature (which represented both the annual cycle and upwelling), as well as modeled alongshore currents, in situ sea-level, and modeled tide. Microbial beta-diversity correlated positively with significant wave height and alongshore currents from models, remotely-sensed relative turbidity, and in situ temperature. We found that archaea from the order Marine Group II decrease with increases in significant wave height, suggesting that this taxon may be influenced by waves. Also, during times of high wave activity, the relative abundance of bacteria from the order Flavobacteriales increases, which may be due to resuspension and cross-shelf transport of sediments. We also found that bacteria from the order SAR86 increase in relative abundance with increased temperature, which suggests that this taxon may play a role in the coral microbiome during periods of higher temperature. Overall, we find that physical oceanographic variability correlates with the structure of these coral microbiomes in ways that could be significant to coral health. 


\author{
Oceanographic habitat and the coral microbiomes of urban-impacted reefs \\ Authors: Stephanie M. Rosales ${ }^{1,2}$, Christopher Sinigalliano ${ }^{1}$, Maribeth Gidley ${ }^{1,2}$, Paul R. Jones \\ 1,2 , Lewis J. Gramer *,1,2 \\ Affiliations: \\ 1. Atlantic Oceanographic and Meteorological Laboratory, National Oceanographic \\ and Atmospheric Administration, Miami, Florida, USA \\ 2. Cooperative Institute for Marine and Atmospheric Studies, University of Miami, \\ Miami, Florida, USA \\ * Correspondence Author: \\ Lew Gramer ${ }^{1,2}$ \\ lew.gramer@,gmail.com, +1-305-772-7933
}

13

14

Keywords: turbidity, waves, currents, temperature, bacteria, archaea

\title{
Abstract
}

Coral reefs are in decline worldwide. In response to this habitat loss, there are efforts to grow, outplant, and restore corals in many regions. The physical oceanographic habitat of corals - such as sea temperature, waves, ocean currents, and available light - is spatially heterogeneous. We therefore hypothesize that outplant location may affect microbiomes, and ultimately, coral health and restoration success. We evaluated the influence of the physical oceanographic habitat on microbes in wild Porites astreoides and Siderastrea siderea. Tissue samples were collected at four Florida reefs in March, June, and September of 2015. We estimated oceanographic conditions from moored instruments, diver observations, remote sensing data, and numerical models. We analyzed microbiomes using amplicon 16S rRNA high-throughput sequencing data. We found microbial alpha-diversity negatively correlated with in situ sea temperature (which represented both the annual cycle and upwelling), as well as modeled alongshore currents, in situ sea-level, and modeled tide. Microbial beta-diversity correlated positively with significant wave height and alongshore currents from models, remotely-sensed relative turbidity, and in situ temperature. We found that archaea from the order Marine Group II decrease with increases in significant wave height, suggesting that this taxon may be influenced by waves. Also, during times of high wave activity, the relative abundance of bacteria from the order Flavobacteriales increases, which may be due to resuspension and cross-shelf transport of sediments. We also found that bacteria from the order SAR86 increase in relative abundance with increased temperature, which suggests that this taxon may play a role in the coral microbiome during periods of higher temperature. Overall, we find that physical oceanographic variability correlates with the structure of these coral microbiomes in ways that could be significant to coral health.

\section{Background}

Coral reefs face numerous environmental and biological challenges, especially in a changing climate. Understanding how the physical habitat - such as temperature variability, light, and water flow - interacts with biological factors in corals has important implications for managing these sensitive ecosystems. Environmental factors such as wind and surface ocean waves can 
42 contribute to the spatial morphology of coral reefs over time (Gischler et al. 2014). Waves help

43 form organismal and morphometric gradients on reefs (Harborne et al. 2006; Kelly et al. 2014;

44 Kench \& Brander 2006; Porter et al. 2017), driving both coral breakage and intermittent water flow on shallow reefs. Coral health is dependent as well, on geographically fine-scale ocean circulation, which varies inter-annually, seasonally, and over shorter time scales (Feng et al. 2016a; Monismith et al. 2018; Rogers et al. 2013; Shedrawi et al. 2017; Sponaugle et al. 2005). For example, coral larval dispersion and settlement rates are affected by hydrodynamic variability, which ultimately impacts gene flow and the genetic diversity of coral reefs (Baums et al. 2006; Serrano et al. 2014; Serrano et al. 2016).

Oceanographic processes can also affect the distribution of nutrients across a reef (Zhang et al. 2011). Currents and upwelling can bring nutrients from the ocean to reefs, and also flush water that has been depleted of nutrients. Nutrient uptake by corals is also augmented by increased wave orbital motion and wave-driven circulation (Hearn et al. 2001; Lowe \& Falter 2015), especially in shallow reefs (Zhang et al. 2011). Additionally, upwelling on coral reefs the upward, onshore motion of cooler waters from the subsurface ocean (Gramer et al. 2018; Leichter et al. 1996) - can aid in both survival and recovery from a bleaching event (Bayraktarov et al. 2013; Tkachenko \& Soong 2017). For instance, in Tayrona National Natural Park in Colombia, corals that underwent bleaching recovered by $97 \%$ in areas where seasonal upwelling occurred (Bayraktarov et al. 2013).

The health of corals is associated with the structure and composition of their microbial communities. With healthy corals showing microbial patterns distinct from diseased or stressed colonies (Glasl et al. 2016; Kimes et al. 2010; Roder et al. 2014). Coral microbiomes respond to both biotic and abiotic fluctuations. While many studies have examined the effects of temperature on coral microbiomes (Bourne et al. 2008; McDevitt-Irwin et al. 2017; Zaneveld et al. 2016), fewer studies have examined the relationship of coral microbiomes to other physical oceanographic variables, such as water flow (including tides and wave-driven flow) and available light (or turbidity). A recent study evaluated the changes in microbial communities in the coral Coelastrea aspera during a $4 \mathrm{~d}$ spring tide event in Phuket, Thailand (Sweet et al. 2017). It was observed that spring tides induced changes in microbial composition that were likely driven by transient microbial members. Another recent study showed that Acropora muricata corals exposed to higher rates of water flow in both tank and in situ experiments have a more stable microbiome (Lee et al. 2017). Coral reefs with higher impacts from turbidity showed a relative increase in opportunistic bacterial pathogens, and a decrease in symbiotic bacteria (Ziegler et al. 2016). Also, one recent study found that temperature and available light affected prokaryotic communities associated with the tissue of Pocillopora damicornis, a common brooding coral in the Indo-Pacific (van Oppen et al. 2018).

Studies like those highlighted above, provide evidence that the physical habitat can impact coral microbial community members and suggests that this may affect the health of the host. In 2008, it was estimated that southeast Florida reefs had less than 5\% live coral cover, compared to higher values in prior decades (Gilliam 2009). As a result of this ongoing decline (Lirman et al. 2011), there are now efforts to restore and outplant corals in Florida (Lirman \& Schopmeyer 2016; Young et al. 2012). Both site selection and host genetics have been shown to be strong indicators for growth in outplanted corals (Drury et al. 2017). Nonetheless, there is still a lack of information in the literature on precisely which physical habitat characteristics can increase the incidence of beneficial coral microbes and ultimately increase rates of coral survival (Glasl et al. 2016). 
88

89

90

91

92

93

94

95

96

97

98

99

100

101

102

103

104

105

106

107

108

109

110

\section{Methods}

\section{Study region}

113 The Florida reef tract (FRT) is a coral reef system in the USA, that stretches from the Dry

114 Tortugas ( $83.0 \mathrm{~W}, 24.5 \mathrm{~N}$ ) east and north to the lower edge of the South Atlantic Bight $(80.0 \mathrm{~W}$,

$11527.3 \mathrm{~N}$ ). The northern third of the FRT lies along the southeast Florida shelf, offshore of Miami-

116 Dade, Broward, and two other counties. For this study, four reefs were sampled (Fig. 1):

117 Barracuda and Oakland Ridge reefs in Broward, and Emerald and Pillars reefs in Miami-Dade.

118 Three distinct sites within each reef were selected for replicate coral tissue collections, resulting

119 in a total of 12 sampling sites. These sites are in waters between 6 and $12 \mathrm{~m}$ deep, and lie

120

\section{1}

122

123

124

125

126

127 between 1.1 to $5.5 \mathrm{~km}$ offshore of mainland Florida.

\section{Sample collection}

The data for this study were leveraged from previous projects. Details about the sites and collection methods have previously been presented (Sinigalliano et al. 2018; Staley et al. 2017). Briefly, samples for this study were collected during March, June, and September of 2015 (see Table 1). Visually healthy corals were sampled at random from two coral species, Porites astreoides and Siderastrea siderea, with SCUBA and a syringe biopsy method. This entailed loosening the polyps from the calyx by gently scrapping/digging at the polyp tissue before 
128 adhering a $5 \mathrm{~mL}$ syringe against the coral polyp to create a suction and extract that polyp from 129 the coral head. This was repeated twice per coral head and combined into one sample in the lab.

130 When divers reached the boat, samples were transferred to a $50 \mathrm{~mL}$ tube with $45 \mathrm{~mL}$ of $95 \%$

131 molecular grade ethanol, placed on ice, then preserved at $-80^{\circ} \mathrm{C}$ at the NOAA AOML laboratory.

132 In addition, divers measured sea temperature with a dive-watch (see Physical oceanographic habitat analysis), and both overall and per-species coral cover and coral mean size (Sinigalliano et al. 2018) at each of the reef sites. A total of 24 P. astreoides and 31 S. siderea samples were collected across four reefs (Barracuda, Oakland Ridge, Emerald, and Pillars) during the three months of sampling (March, June, and September).

DNA extractions and microbiome amplicon sequencing

Coral polyps, which included the tissue and remnant mucus, were processed for DNA extraction and sequencing, briefly as follows (Staley et al. 2017): samples were vortexed to resuspend coral tissue, and the entire contents were placed on a $0.2 \mu \mathrm{m}$ polycarbonate filter under a vacuum. Both the filter and any residual large coral tissue were transferred to a bead beating Lysing Matrix "E" tube. The samples were then homogenized by bead beating with a FastPrep 24 instrument (MP, Biomedical) by two separate rounds of bead beating at an impact speed of 6.0 $\mathrm{m} / \mathrm{s}$ for 60 seconds each (for a total of 120 seconds at $6 \mathrm{~m} / \mathrm{s}$ ). Each lysed sample was then purified with the FastDNA SPIN kit for soil DNA Extraction (MP, Biomedical) following the manufacturer's instructions and eluted in $100 \mu \mathrm{L}$ of TE buffer. DNA was amplified using dual index primers, $515 \mathrm{~F}$ and $806 \mathrm{R}$, that target the variable-4 (V4) region of the $16 \mathrm{~S}$ rRNA gene. Amplified DNA was sequenced on the MiSeq platform, generating paired-end reads of 300 base pairs (bps).

\section{Bioinformatic analysis}

Demultiplexed sequences from the 55 samples were retrieved from the National Center for Biotechnology Information (NCBI) Sequence Read Archive (SRA) database (\#SRP076111). Once downloaded, the sequence primers were trimmed using the program cutadapt. The sequences were analyzed with qi ime2-2018. 6 using the DADA2 pipeline for classification of amplicon sequence variants (ASVs), and were run with a max expected error (maxEE) of 2 (Callahan et al. 2016). To select sequence trimming positions, the quality score of a random set of sequences were analyzed. Where sequences showed a drop-in quality score $(<\mathrm{Phred}=30)$, those base pair (bp) positions where chosen for trimming. All forward sequences were truncated to the same length of $220 \mathrm{bps}$ and trimmed at the first $8 \mathrm{bps}$. The reserve reads were also truncated to be of the same length at $120 \mathrm{bps}$, and trimmed at the first $20 \mathrm{bps}$. The DADA2 pipeline was used for ASV selection, dereplication, merging paired-end reads (min overlap $=20 \mathrm{bps}$ ) and removing chimeras (with the "consensus" option). Taxonomy was assigned with the Silva database version 132 training set, which was trained on the V4 region by the fitclassifier classify-sklearn function. Only sequences that were taxonomically identified as Bacteria or Archaea were analyzed. The biome data, ASV table, fasta file, phylogenetic tree, and metadata for this analysis can be found on figshare (DOI:10.6084/m9.figshare.7388672). The specific NCBI accession number for each sequence file is listed under "sampleID" in the metadata file. 


\section{Statistical analysis}

170 Microbial alpha-diversity was evaluated with qi ime2-2018.6, using the Shannon diversity

171 index and species evenness metrics. To asses alpha-diversity, ASV counts were rarefied to

172 (randomly filtered to an equal sequencing depth of) 403 counts, so that all 55 samples could be

173 evaluated. Since 403 is a low number of sequences, the ASV table was also rarefied to 2,055

$174(\mathrm{~N}=53)$. We compared these two methods and since both methods resulted in the same

175 conclusions, a rarefaction of 403 was used in order to include all 55 samples in alpha-diversity

176 analysis. Categorical habitat data (see Table 1) were tested for significant relationships with

177 Shannon diversity index and species evenness using the alpha-group-significance

178 function, which applies a pairwise/all-group Kruskal-Wallis test (Gregr \& Bodtker 2007).

179 Continuous habitat data (see Table 1) were tested vs. alpha-diversity with a simple linear

180 regression, using the function $1 \mathrm{~m}$ on R.3.4.3.

181 For beta-diversity tests, the data were not rarefied, but instead were filtered by retaining

182 only those taxa that were seen four or more times in at least $10 \%$ of the samples. The counts

183 were then transformed into relative abundances. Continuous habitat data were evaluated for

184 pairwise covariance; from each pair with a correlation $>80 \%$, one variable was selected for

185 further analysis. Principal coordinate analysis (PCoA) ordination was applied to the relative

186 abundance of ASVs with a weighted UniFrac distance metric (Lozupone \& Knight 2005).

187 Discrete variables (i.e., reef site, species, and month) were tested using Analysis of similarities

188 (ANOSIM) and a Permutational multivariate analysis of variance (PERMANOVA) with 999

189 permutations to identify which groups were different (Clarke \& Warwick 1994). The counts

190 matrix was also used to build a model with forward and backward model selection, using the

191 Vegan function ordistep, which selects significant variables that best explain the counts data.

192 Prior to inputting habitat variables into ordistep, their respective variance-inflation factors

193 (Salmeron et al. 2018) (VIF) were tested; variables with a VIF score $>20$ were removed from

194 further analysis. The variables selected by the model were then used to construct a canonical or

195 constrained correspondence analysis (CCA) (Henriques et al. 2006). These statistical analyses

196 were conducted with the packages Vegan 2.4.6 and phyloseq 1.22.3.

197 To further evaluate patterns seen in the beta-diversity results, we used a classification

198 method to evaluate which microbial taxa were important to the physical habitat variables that

199 were found to be significant using ordistep (above). The classification method used on each of

200 the significant physical habitat variables was the sample-classifier regress-

201 samples function from qiime2. This function performs random forest (a supervised machine

202 learning algorithm) and was used with parameters --p-parameter-tuning, --p-estimator

203 RandomForestRegressor (RFR), and --p-n-estimators 500. The model outputs importance values

204 and the highest importance values have the greatest prediction power. Thus, the five taxa with

205 the highest importance values from each random forest test were selected for simple linear

206 regression analysis vs. the corresponding physical habitat variable. Only the taxa with a

207 significant correlation $(\mathrm{p}<0.05)$ and a coefficient of determination $\mathrm{R}^{2}>0.2$ were plotted. The

208 code for the statistical analysis for the microbial data and the corresponding figures are found on

209 figshare (DOI:10.6084/m9.figshare.7925495). 


\section{Physical oceanographic habitat analysis}

211 The minimum near-bottom sea temperatures were collected by divers (see Sample collection).

212 Replicates for each measurement are listed in Table 1. Seafloor depths (bathymetry) were

213 derived from NOAA's 10 m horizontal-resolution port-bathymetry project (Carignan et al.

214 2015). From bathymetry, we estimated local seafloor depth ([m]), seafloor slope (rise/run),

215 isobath orientation (alongshore direction, deg. True), and distance from each sampling site to the

216 nearest major inlet running through the Intracoastal Waterway (Fig. 1 and Table 1).

217

218

219

220

221

222

223

224

225

226

227

228

229

230

231

232

233

234

235

236

237

238

239

240

241

242

243

244

245

246

247

248

249

250

251

252

253

254

Satellite multispectral ocean-color was used to produce a proxy for in-water turbidity, a product called relative turbidity or color index (CI). Since 2000, the MODerate-resolution Imaging Spectrophotometer (MODIS) instruments aboard the polar-orbiting Aqua and Terra satellites have produced multispectral ocean color data at $250 \mathrm{~m}$ horizontal resolution. CI datasets were produced from these data, using an algorithm developed by the University of South Florida's Optical Oceanography Laboratory (Barnes et al. 2015).

The CI product is subject to bias in shallow waters where the seafloor may be visible from space. In this study, CI values were normalized using the median and 7th and 93rd percentiles for 15 years of CI data (2000-2015) from each pixel. Percentile values were used because CI for coastal pixels is often not normally distributed (Gramer \& Hendee 2018). On days when clouds obscured a pixel during one or both daytime satellite overpasses, no CI value was available for that site. Therefore, for the purposes of this study, we used a $14 \mathrm{~d}$ arithmetic mean of CI values centered on each sample date, resulting in relative turbidity time series with no gaps (Fig. 2A-C). Finally, time series for satellite CI were validated by linear regression vs. in-water turbidity measurements (NTU) done with boat-based casts using a factory-calibrated nephelometer throughout the sampling period (2013-2015) (Supplementary Fig. S1; Staley et al. 2017).

Ocean currents were extracted as daily snapshots from the Gulf of Mexico HYbridCoordinate Ocean Model (GoM HYCOM; Gierach et al. 2009) at the vertical layer closest to the surface. Northward and eastward vector-components were bilinearly interpolated from native model resolution ( $1 / 25$ th degree) to individual sampling location. Current vectors were then rotated so that positive cross-shore currents were directed perpendicular to the local isobath (i.e., "offshore") at each site. Daily snapshots of currents from GoM HYCOM alias the diurnal and semidiurnal tidal cycles, showing the distinct signature of the $27.55 \mathrm{~d} \mathrm{M}_{\mathrm{m}}$ tidal constituent. Furthermore, although we expect GoM HYCOM to provide useful statistics for the amplitude of lower-frequency (multi-day) current variability, the model may not always correctly model the phase of that variability (Gramer 2013). Thus, centered moving $14 \mathrm{~d}$ averages of each current component (cross-shore and alongshore) were analyzed (Fig. 2D-F).

To estimate surface wave action, we used significant wave height from NOAA's WaveWatch III multi-mesh grid operational model for the western Atlantic, with 4 nautical-mile nominal resolution (Lee et al. 2009; Tolman 2014). A wave attenuation algorithm was applied to wave height, bilinearly interpolated to the horizontal resolution of the bathymetry $(10 \mathrm{~m})$ (Supplementary Fig. S2; Gramer \& Hendee 2018). This algorithm linearly reduces significant wave height at bottom-depths between $0-20 \mathrm{~m}$, resulting in high-resolution wave fields that reach all the way inshore, with zero wave-height at the beach (Supplementary Fig. S3).

Ocean model outputs and diver-watch sea temperatures were validated using in situ hourly observations from acoustic Doppler current profilers (ADCP) (Supplementary Fig. S4). These ADCPs were moored at two sites, one at 7 and one at $26 \mathrm{~m}$ depth, $6 \mathrm{~km}$ north of 
255 Barracuda Reef (Sinigalliano et al. 2018). They measured near-bottom sea temperatures

256 (nominal accuracy $0.01 \mathrm{~K}$ ) and three-dimensional ocean current profiles (bin sizes $0.5 \mathrm{~m}$ at $7 \mathrm{~m}$

257 depth and $1 \mathrm{~m}$ at $26 \mathrm{~m}$, nominal accuracy $10^{-4} \mathrm{~m} \mathrm{~s}^{-1}$ ) every $20 \mathrm{~min}$ throughout all three sampling

258 periods of March, June, and September of 2015.

259

260

261

262

263

264

265

266

267

268

269

270

271

272

273

274

275

Tide heights for each site were modeled using the TPXO 7.2 global tide solution (Stammer et al. 2014). Hourly in situ measurements of near-bottom sea-pressure from the FACE mooring at $7 \mathrm{~m}$ depth were also used with mean depth removed ("sea-level anomaly"), both to validate model tide-stage predictions and to consider the additional effects of setup from wind, waves, and larger-scale sea-level variation offshore. The time of day of collection was not logged for the tissue samples analyzed in this study, nor can the TPXO 7.2 global solution model finescale variability in tide heights and currents on the topographically complex southeast Florida shelf ( $\sim 1 \mathrm{~km}$, diurnal or faster). For these reasons, a $14 \mathrm{~d}$ centered average of both the modeled tide height and the sea-level anomaly (Supplementary Fig. S5) were analyzed in the present study. The Ecoforecasts toolkit, a set of MATLAB functions developed by Gramer as a part of NOAA CHAMP, was used to produce some time series analyses and maps presented here. Due to the prevalence of non-Gaussian distributions in habitat data (Supplementary Fig. S6), results for habitat variables are cited as median \pm half of interquartile range values. Elsewhere, e.g., for relative abundances, mean and standard deviation are reported. The code used to generate physical ocean habitat variables and the corresponding figures are found on figshare (DOI: 10.6084/m9.figshare.7925546).

\section{Results}

\section{The physical oceanographic habitat of four southeast Florida coral reefs in} 2015

To extract all other physical habitat variables for each of the four reefs, we used longitude and latitude coordinates from each of the 12 sample-collection sites (three sites per reef, Fig. 1) together with the dates of sampling, as described in the Methods. March was a period of geographic patchiness in CI (Fig. 2A). However, patchiness was largely confined during March sampling dates to waters away from the sampling sites. On the other hand, both June and September (Fig. 2B-C) showed less intense regional patchiness, but patches of higher relative turbidity did reach some of the sites during sampling. Satellite relative turbidity (CI) showed a complex seasonal pattern than the other variables considered (Fig. 3C). The highest extreme and the greatest range of values occurred during June sampling ( -0.43 to 0.23 , median -0.16$)$, with sampling in September scattered over a mainly lower range ( -0.50 to -0.08 , median -0.23$)$, and that from March clustered within a very narrow range ( -0.13 to -0.04 , median -0.09$)$. Barracuda was the reef that experienced the greatest positive and negative extremes of normalized CI during the 2015 sampling, with a peak at the three Barracuda sites of between +0.06 and +0.23 on the sampling day of June 12 th, and lows between -0.30 and -0.50 on September 11 th. Interestingly, June was also the month with the highest CI value at Oakland Ridge (0.11), despite lower modeled waves. (Results of regressing satellite CI values vs. in-water turbidity measurements are shown in Supplementary Fig. S1) 
Alongshore currents from the Gulf of Mexico HYCOM model (Fig. 2D-F and Fig. 3D) showed a relative peak at all sampling sites during June, with weekly medians of +0.30 to +0.65 $\mathrm{m} \mathrm{s}^{-1}$ (positive being a northward current). Further peaks in July and August were followed by a rapid decline during sampling weeks in September, to medians of +0.10 to +0.45 , which was also similar to medians during the March sampling. At the time of coral tissue sampling, in situ ocean current profilers were deployed near the sampling sites. The midsummer peak could also be seen in these instruments (Fig. 3D, gray and black lines). According to climatology models (Fig. 2E), this summer peak corresponded to a westward meander of the Florida Current; this June meander however affected the southernmost sampling sites, those at Emerald Reef (median $+0.60 \pm 0.00$ $\mathrm{m} \mathrm{s}^{-1}$ ), more than at the other three reefs (medians +0.30 to $+0.48 \pm 0.01 \mathrm{~m} \mathrm{~s}^{-1}$ ). Emerald Reef actually experienced higher alongshore currents than the other sites during all three sampling months, although these differences were less extreme in March and September than they were in June.

The minimum diver-watch sea temperature was recorded during each tissue-sampling dive (Table 1). For validation, dive-watch temperatures were compared to sea temperatures measured at two moorings (that at 7 and that at $26 \mathrm{~m}$ depth). Dive-watch sea temperature followed closely the coincident mooring temperatures at $7 \mathrm{~m}$ (Fig. 3A; black line): regressions were significant $(p<0.0001$, Supplementary Fig. S4), with root mean-squared error (RMSE) 0.28 at Barracuda, 0.78 at Oakland Ridge, 0.31 at Pillars, and $0.29 \mathrm{~K}$ at Emerald. Regressions vs. the deeper mooring at $26 \mathrm{~m}$ were also significant $(\mathrm{p}<0.05)$ with RMSE of 0.8 at Barracuda, 1.0 at Oakland, 0.34 at Pillars, and $0.25 \mathrm{~K}$ at Emerald.

Like the moorings, dive-watch sea temperature across the four reefs followed a seasonal pattern (Fig. 3A). For March, there was a median 23.2 and interquartile range \pm 0.4 , for June 28.0 \pm 0.2 , and for September $29.2 \pm 0.5^{\circ} \mathrm{C}$. However, temperatures were somewhat cooler than might be expected from historical in situ measurements in this region, especially during the warmer months (Gramer et al. 2018). In particular, the mooring at $7 \mathrm{~m}$ depth (Fig. 3A) recorded nearbottom temperatures of $24.7 \pm 0.5$ in March, $29.2 \pm 0.9$ in June, and $31.2 \pm 0.4{ }^{\circ} \mathrm{C}$ in September of 2015. Similarly, near-surface temperature measurements in $2 \mathrm{~m}$ of water at the nearby Virginia Key pier (NOAA National Ocean Service station "VAKF1") showed warmer temperature ranges in June and September of $29.7 \pm 1.1$ and $30.1 \pm 0.6^{\circ} \mathrm{C}$, respectively (Fig. 3A; red line).

Wave heights from the attenuated NOAA model showed a relatively simple seasonal pattern for all sites (Fig. 3B), with the highest waves at all sites during sampling in March (0.25$0.35 \mathrm{~m})$, and intermediate waves during sampling in late September $(0.2-0.3 \mathrm{~m})$. Waves in June were generally lower $(0.15-0.25 \mathrm{~m})$, due to the absence of storm systems in the nearby Atlantic and Gulf of Mexico, and to generally light local summer winds. The lowest wave estimates, however, were those for samples taken in early September at Oakland Ridge and Barracuda (0.08 $\mathrm{m}$ ); these two reefs were generally the most sheltered (Fig. 1 and Supplementary Fig. S3). Furthermore, these samples were gathered prior to a series of wind events in mid-September, and perhaps more importantly, prior to the development of a major tropical weather system in the Atlantic in late September (Fig. 3B; see Discussion).

Tide models used for this study do not provide sufficient spatial or phase resolution to estimate diurnal or semidiurnal variability in water heights or tidal currents. However, these models do resolve variability between sites associated with the $\mathrm{M}_{\mathrm{m}}$ tidal constituent, which has a $27.55 \mathrm{~d}$ period. Tide height variations for this constituent were at or near their minimum $(-0.008$ to $-0.005 \mathrm{~m}$ ) during all March sampling dates. In June, sampling was done near the $\mathrm{M}_{\mathrm{m}}$ peak $(+0.002 \mathrm{~m})$ at all reefs except Oakland Ridge, where samples were gathered near the time of the 
343 minimum or ebb $\mathrm{M}_{\mathrm{m}}(-0.005 \mathrm{~m})$. Similarly, September samples were collected near the ebb at 344 both Oakland Ridge and Barracuda ( -0.006 to $-0.004 \mathrm{~m}$ ), and near the peak at Pillars and 345 Emerald Reef $(+0.001 \mathrm{~m})$.

\section{Fictibacillus and Endozoicomonas were dominant bacterial members in two} hard coral species in four southeast Florida reefs

The 55 16S rRNA amplicon sequences from coral tissue samples (24 P. astreoides and 31 S. siderea) were leveraged from a previous study (Staley et al. 2017). The program DADA2 identified a total of 22,451 ASVs and after filtering, 15,201 ASVs remained. The minimum frequency of an ASV per sample was 404 and the maximum frequency was 196,536. The median ASV frequency per sample was 102,667 with a mean of 98,118 .

The microbial taxa of the samples are summarized in Fig. 4. On average, across the four Southeast Florida reefs in 2015, the bacterial genus Fictibacillus, family Bacillaceae made up the majority of the microbial community $(\mathrm{N}=55$; mean relative abundance, meanRA $=13.9 \%, \pm$ standard deviation 1.8\%). The bacterial genus Endozoicomonas, family Endozoicomonadaceae also had a high meanRA $(12.2 \% \pm 9.7 \%)$. When analyzing the two host-species separately, $P$. astreoides was dominated by Endozoicomonas $(\mathrm{N}=24 ; 10.7 \% \pm 8.0 \%)$; S.siderea on the other hand, had a higher abundance of the genus Fictibacillus $(\mathrm{N}=31 ; 10.4 \% \pm 11.1 \%)$, while Endozoicomonas was only this host's 9 th most abundant taxon $(1.5 \% \pm 3.0 \%)$. During the month of September $(\mathrm{N}=24)$ specifically, across samples from both host species, the family Bacillaceae was found at higher abundances, and was composed of the genera Paenibacillus $(8.9 \% \pm 12.2 \%)$ and Fictibacillus $(7.7 \% \pm 9.6 \%)$. However, for the months of March $(\mathrm{N}=20)$ and June $(\mathrm{N}=11)$, across all sites and both host species, Endozoicomonas showed the highest meanRA of $4.5 \% \pm$ $5.2 \%$ (March) and $5.2 \% \pm 9.0 \%$ (June). Two reef sites had the highest overall average abundances for Fictibacillus across all months and both hosts: Barracuda $(\mathrm{N}=16 ; 4.3 \% \pm 10.0 \%)$ and Emerald $(\mathrm{N}=10 ; 3.8 \% \pm 9.6 \%)$. The other two reefs showed their highest overall average abundances for Endozoicomonas across month and host: Oakland Ridge (N=13;4.9\% $18.0 \%)$ and Pillars $(\mathrm{N}=16 ; 4.3 \% \pm 6.8 \%)$.

\section{Bacterial alpha diversity correlated with the physical oceanographic habitat}

Table 1 lists three (3) categorical and 14 numerical variables. Twelve physical habitat variables were selected for analysis to identify univariate correlations between these variables and coral microbiomes (Overall coral cover and overall mean size were not considered; only coral cover and mean size for the two host species were considered - P. astreoides and $S$. siderea.). Latitude and longitude were removed from this analysis, as they correlated $(\rho>80 \%)$ with other independent habitat variables.

Microbial Shannon diversity was negatively correlated with alongshore current speed $\left(R^{2}=0.05, p=0.044\right)$, tide height $\left(R^{2}=0.12, p=0.004\right)$, and temperature $\left(R^{2}=0.13, p=0.002\right.$; Fig. 
386

387

388

389

390

391

392

393

394

395

396

397

398

399

400

401

402

403

404

405

406

407

408

409

410

411

412

413

414

415

416

417

418

419

420

421

422

423

424

425

426

427

$5 \mathrm{~A}-\mathrm{C})$. Similarly, microbial evenness was negatively correlated with sea-level $\left(\mathrm{R}^{2}=0.09\right.$, $\mathrm{p}=0.014)$, tide height $\left(\mathrm{R}^{2}=0.12, \mathrm{p}=0.005\right)$, and temperature $\left(\mathrm{R}^{2}=0.15, \mathrm{p}=0.002\right.$; Fig. 5D-F $)$. Among independent categorical variables, host species was significant to Shannon diversity $(p=0.04)$. With regard to interactions between sampling months, pairwise comparisons were significant for both Shannon and evenness $(p<0.05)$ for March vs. June and March vs. September, but not for June vs. September. Finally, there were no significant pairwise differences between reefs, in either Shannon diversity or evenness.

\section{Coral bacterial community composition correlated with physical} oceanographic habitat

In the beta-diversity analysis, ordination axis 1 of the principal coordinate analysis (PCoA) explained $89.5 \%$ of the variance, and PCoA 2 explained $5.8 \%$ of the variance (Fig. 6A). Of correlations between the 12 numeric habitat variables considered, and axis 1 or axis 2 of the ordination, only relative turbidity was significant to axis $2\left(\mathrm{R}^{2}=0.27, \mathrm{p}<0.05\right)$. In addition, for categorical variables, an ANOSIM showed that the microbial community correlated with host species $\left(\mathrm{R}^{2}=0.38, \mathrm{p}=0.001\right)$ and month $\left(\mathrm{R}^{2}=0.21, \mathrm{p}=0.001\right)$, but not with reef location $\left(\mathrm{R}^{2}=0.04\right.$, $\mathrm{p}=0.094)$. A PERMANOVA also showed the same results for host-species $(p>0.001)$, month $(p$ $>0.001)$, and reef location $(\mathrm{p}=0.86)$. Four of the 12 habitat variables had explanatory power for the microbiome count matrix: alongshore currents $(p=0.005)$, relative turbidity $(p=0.015)$, significant wave height $(\mathrm{p}=0.005)$, and temperature $(\mathrm{p}=0.005)$. All four of these variables had a variance-inflation factor (VIF, diagonal of the inverse of the correlation coefficient matrix) $<2$, indicating that they represent effects which are independent of one another (Salmeron et al. 2018).

The canonical or constrained correspondence analysis (CCA) ordination was constrained by these four habitat variables, with CCA1 and CCA2 verified as significant by one-way ANOVA. Categorical data were analyzed vs. CCA1 and CCA2: month $\left(\mathrm{R}^{2}=0.52, \mathrm{p}=0.001\right)$ and reef- $\left(\mathrm{R}^{2}=0.15, \mathrm{p}=0.009\right)$ were found to be significant, but the host species was not. Given that host species was not a significant factor to CCA, we analyzed samples from both species together. Accordingly, the CCA ordination plot annotated by month and reef (Fig. 6B) shows that microbial communities cluster primarily by month, with samples collected in March $(\mathrm{N}=20)$ correlating with significant wave height and relative turbidity, and samples collected in September $(\mathrm{N}=24)$ correlating with temperature; samples collected in June $(\mathrm{N}=11)$ correlated with alongshore current speed.

\section{Microbial taxa correlated with changes in waves and temperature}

To identify individual microbial taxa that correlated with changes in the physical oceanographic habitat, we used a Random Forest Regressor (RFR) for variable selection, and then applied a simple linear regression on individual variables. Based on ordistep model outputs, we analyzed four variables with RFR - significant wave height, relative turbidity, alongshore currents, and sea temperature. The RFR classification model was significant for significant wave height $\left(\mathrm{p}<0.001, \mathrm{R}^{2}=0.85\right)$, alongshore currents $\left(\mathrm{p}<0.01, \mathrm{R}^{2}=0.60\right)$, and sea temperature $\left(\mathrm{p}<0.001, \mathrm{R}^{2}=0.85\right)$. The model was not significant for relative turbidity $\left(\mathrm{p}=0.92, \mathrm{R}^{2}=0.001\right)$. The five microbial taxa with the highest importance values from each significant RFR model are 
428

429

430

431

432

433

434

\section{5}

436

437

438

439

440

441

442

443

444

445

446

447

448

449

450

451

452

453

454

455

456

457

458

459

460

461

462

463

464

465

466

467

468

469

470

471

listed in Supplementary Table 1. That table also notes which of these "important" taxa were significantly correlated $\left(\mathrm{p}<0.05, \mathrm{R}^{2}>0.2\right)$ with their respective habitat variables. For significant wave height, two taxa were significant from the order Flavobacteriales, and one from Marine Group II. For temperature, one taxon was significantly correlated from the order SAR86 (Fig. 7). There were no microbial taxa that were found to be correlated significantly with alongshore currents (i.e., none with $\mathrm{p}<0.05$ and $\mathrm{R}^{2}>0.2$ ).

\section{Discussion}

In our study, we found distinct interactions of individual physical habitat variables with multiple microbiome structure variables. These physical oceanographic habitat variables do covary with one another over a range of time and space scales. For example, water temperatures can be driven by thermal advection, temperature gradients can force water flow through horizontal convection, and turbidity is often the result of wave breaking. Recent published results have demonstrated that indeed, the complex interaction between physical variables like flow, light, and temperature may potentiate their effects on coral microbiomes (Lee et al. 2017; van Oppen et al. 2018). To add to the complexity of these physical habitat factors, a combination of physico-chemical components also works together to affect the microbial communities on coral reefs (Roik et al. 2016). However, here, we aimed to tease apart which univariate responses of the coral microbiome to individual habitat variables were significant.

Our results show that $95 \%$ of the variance in microbial beta-diversity was explained in the first two PCoA axis, and that coral species had the highest group separation $\left(\mathrm{R}^{2}=0.38\right)$ among categorical factors (i.e., month, species, reef; Fig. 6A). Coral species (P. astreoides and $S$. siderea), each have a unique microbial diversity composed of different taxa (Fig. 4 and Fig. 6A). However, we also found correlations across the two host species, between coral microbiomes and temperature, turbidity (related to available light), and multiple scales of waterflow (i.e., those related to modeled larger-scale ocean currents, smaller-scale responses to sea-level gradient, and waves).

We found that increases in tide height, sea-level, sea temperature, and modeled alongshore currents were associated with declines in microbial Shannon diversity and/or evenness (Fig. 5). Among shallow coastal environments such as those on tidal flats, tide changes affect the structure and function of the microbial community (Lü et al. 2016). Similarly, studies of reefs below the tidal zone have shown that differing seawater depths (related to available light and flow regimes) do correlate with changes in bacterial communities (Bonthond et al. 2018; Klaus et al. 2007; Pantos et al. 2015). Although we found increased sea-level and tide height both independently associated with decreased alpha-diversity, we cannot state which specific physical process explains these results. This is because the overall range of relative water height variations observed in this study from both modeled tides and direct (moored sea pressure) measurements was small, $0.25 \mathrm{~m}$ or less than $5 \%$ of the shallowest mean site depths (Supplementary Fig. S2). Hence, any influence that sea-level (including tides) had on these microbiomes was more likely due to low-frequency variability in currents and/or transports forced by sea-level gradients, rather than to the sea-level variations themselves. In particular, low-frequency variability from both wind setup and tide can drive cross-shelf transport (Castelao et al. 2010; Lee \& Smith 2002; Leichter et al. 1996), affecting microbial connectivity (Sawstrom et al. 2016), flushing times (Castelao et al. 2010), and the availability of prey and nutrient inputs 
472 (Leichter et al. 2003; Monismith et al. 2010; O'Connell et al. 2018). Such effects may serve to

473

474

475

476

477

478

479

480

481

482

483

484

485

486

487

488

489

490

491

492

493

494

495

496

497

498

499

500

501

502

503

504

505

506

507

508

509

510

511

512

513

514

515

516

517 reduce microbial alpha-diversity on reefs (O'Connell et al. 2018) and may explain the correlations we observed.

For beta-diversity, the four habitat variables that best describe the data were significant wave height, alongshore currents, relative turbidity, and temperature. In March, microbial betadiversity was correlated (Fig. 6B) with high multi-site median relative turbidity (Fig. 3C, all sites) and a range of significant wave heights between reefs (Fig. 3B, e.g., Pillars vs. Oakland Ridge). Corals sampled in the present study were at bottom depths between 6 and $12 \mathrm{~m}$ and thus, were likely to be influenced by waves of the amplitudes we found from the model (Fig. 3 and Supplementary Fig. S3), both from orbital motions (Rogers et al. 2015) and wave-driven circulation (Rogers et al. 2018).

In response to significant wave height, we found that a euryarchaeotal taxon from Marine Group II decreased throughout the study period with increases in wave height (Fig. 7A). Euryarchaeota are known microbiome members in corals, with the majority of this taxon belonging to Marine Group II (Siboni et al. 2008). However, no study, to our knowledge, has described the role played by these archaea in coral microbiomes (Bourne et al. 2016). Our analysis suggests that Marine Group II may play a larger role in the coral microbiome during times of lower wave activity such as June and, at some sites, in September. In March, during times of higher wave activity, there was an increase in relative abundance of the bacterial order Flavobacteriales, genus Tenacibaculum (Fig. 7A). The genus Tenacibaculum encompasses bacteria that are associated with the marine environment and can be pathogenic (Park et al. 2016; Smage et al. 2016). This Tenacibaculum ASV has a 100\% sequence identity with Tenacibaculum sediminilitoris - an isolate from tidal flats (Park et al. 2016). Both tidal flat sediments and seawater are sources of Tenacibaculum; therefore, it is possible that the presence of this genus during high wave activity is due to sedimentation resuspension.

The CI dataset is designed to map out visible influences of inshore events on coral reefs using satellite ocean color data. This applies equally to plumes associated with the effects of breaking waves inshore, and those potentially attributable to human activities. High turbidity on the shelf can be due to waves through erosion or sediment resuspension. However, when turbidity occurs in the absence of higher waves (Fig. 3B-C), as it did at some sites in March (Oakland Ridge and Emerald) and again in June (Barracuda and Oakland Ridge), it is considered more likely to be due to human activities such as dredging or flood control (Barnes et al. 2015; Gramer \& Hendee 2018). Indeed, a major port expansion was ongoing at Port of Miami, approximately $9 \mathrm{~km}$ east-southeast of Emerald Reef, and 13, 37, and $46 \mathrm{~km}$ from Pillars, Barracuda, and Oakland Ridge, respectively. Primary dredging on this project ended on 08 April 2015, with "spot" dredging that continued into September of 2015. In March alone, we see historically high turbidity throughout the reefs we sampled (Fig. 3C), with a plume that includes the area surrounding the outer channel of Port of Miami (Fig. 2A). Interestingly, in March data, we also see a correlation between relative turbidity and coral microbiome beta diversity (Fig. 6B).

With regard to waves in September, we note that Tropical Storm Joaquin was meandering over waters near the Bahamas beginning on 28 September, and had intensified to a Category 4 hurricane by 01 October. During the final sampling day of the present study on 28 September, this storm appears to have already brought higher significant wave heights to the entire shelf, which affected samples taken at both Pillars and Emerald Reef (Fig. 3B). Modification of the reef environment by remote tropical systems occurs episodically in south Florida (Manzello et al. 
518 2007). This result suggests that tropical weather systems impacted the physical environment of 519 these reefs via wave action (Fig. 2 and Fig. 3). However, we note that waves from this indirect 520 effect were still smaller than those from the direct effect of synoptic weather systems from the

521

522

523

524

525

526

527

528

529

530

531

532

533

534

535

536

537

538

539

540

541

542

543

544

545

546

547

548

549

550

551

552

553

554

555

556

557

558

559

560 previous March (Fig. 3B, all sites). The effect in September was also only sampled at two of the four reefs, due to timing. Either of these differences could explain why microbiome structure related to waves stood out in March, but not in September (Fig. 6).

A number of studies have reported that the microbial community in corals responds to temperature fluctuations (McDevitt-Irwin et al. 2017; Zaneveld et al. 2016). In this study, we also see that coral microbial alpha- and beta-diversity correlated with temperature, with September samples in particular clustering closely together by temperature (Fig. 5 and Fig. 6B). In September, we see an increase in relative abundance in SAR86 from the class Gammaproteobacteria. This bacterium is found in oligotrophic environments and is known to respond to temperature changes (Dupont et al. 2012). It is unknown how this bacterium may affect the host's health, but it may play an important role in P. astreoides and S. siderea holobiont response during times of high temperature (Cardenas et al. 2012; Pootakham et al. 2018).

The pattern of sea temperatures measured by the divers and in situ moorings in September appears consistent with summer-time upwelling superimposed on the annual "weather" cycle, rather than simple annual variability (Fig. 3A). Upwelling is known to occur episodically but frequently on the east Florida shelf (Pitts \& Smith 1997; Walker \& Gilliam 2013), and has been observed to affect temperature on reefs there at a wide range of depths (Gramer et al. 2018). Due to upwelling, some reefs in Florida can experience cooler water temperatures in August and September than they experience in January (Leichter et al. 2006; Walker \& Gilliam 2013). In addition to modifying the thermal environment, upwelling can also enhance the flux of soluble nutrients onto a reef (Gramer et al. 2018). Furthermore, the onset and relaxation of an upwelling event may increase flushing of the shelf environment. A combination of these effects from upwelling may help explain the particular relationship between temperature and microbial community structure that we saw in the clustered data for September.

\section{Conclusions}

In conclusion, we identified physical oceanographic habitat variables that correlate with structure in the microbiomes of two hard coral species on four urban-impacted reefs. Our study, also identified summer upwelling at some of these reef sites, which decreased bottom sea temperatures and may explain some aspects of the observed microbiome structure. The study design, together with our use of regional-scale model and satellite data to characterize the physical habitat, did not allow for lower bounds to be determined on the significant (decorrelation) distances and time scales associated with variability in that habitat, nor the scales of the diversity in the coral microbiomes. Our study, nonetheless, indicates potentially important future considerations for improving coral health and outplant success in Florida reefs. This suggests that targeted, fine-scale future studies should be conducted at outplant sites, combining continuous physical measurements with repeated surveys and biological sampling, in order to further establish the relative importance of various oceanographic habitat characteristics in determining microbiology, coral health, and restoration success.

PeerJ reviewing PDF | (2019:03:36282:1:2:NEW 5 Jul 2019) 


\section{References}

562 Barnes BB, Hu CM, Kovach C, and Silverstein RN. 2015. Sediment plumes induced by the Port

563

564

565

566

567

568

569

570

571

572

573

574

575

576

577

578

579

580

581

582

583

584

585

586

587

588

589

590

591

592

593

594

595

596

597

598

599

600

601

602

603

604

605 of Miami dredging: Analysis and interpretation using Landsat and MODIS data. Remote Sensing of Environment 170:328-339. 10.1016/j.rse.2015.09.023

Baums IB, Paris CB, and Cherubin LM. 2006. A bio-oceanographic filter to larval dispersal in a reef-building coral. Limnology and Oceanography 51:1969-1981.

Bayraktarov E, Pizarro V, Eidens C, Wilke T, and Wild C. 2013. Bleaching susceptibility and recovery of Colombian Caribbean corals in response to water current exposure and seasonal upwelling. Plos One 8:11. 10.1371/journal.pone.0080536

Boehm AB, Lluch-Cota DB, Davis KA, Winant CD, and Monismith SG. 2004. Covariation of coastal water temperature and microbial pollution at interannual to tidal periods. Geophysical Research Letters 31. L06309 10.1029/2003g1019122

Bonthond G, Merselis DG, Dougan KE, Graff T, Todd W, Fourqurean JW, and RodriguezLanetty M. 2018. Inter-domain microbial diversity within the coral holobiont Siderastrea siderea from two depth habitats. Peerj 6:25. 10.7717/peerj.4323

Bourne D, Iida Y, Uthicke S, and Smith-Keune C. 2008. Changes in coral-associated microbial communities during a bleaching event. Isme Journal 2:350-363. 10.1038/ismej.2007.112

Bourne DG, Morrow KM, and Webster NS. 2016. Insights into the Coral Microbiome: Underpinning the Health and Resilience of Reef Ecosystems. In: Gottesman S, ed. Annual Review of Microbiology, Vol 70. Palo Alto: Annual Reviews, 317-340

Callahan BJ, McMurdie PJ, Rosen MJ, Han AW, Johnson AJA, and Holmes SP. 2016. DADA2: High-resolution sample inference from Illumina amplicon data. Nature Methods 13:581+. 10.1038/nmeth.3869

Cardenas A, Rodriguez LM, Pizarro V, Cadavid LF, and Arevalo-Ferro C. 2012. Shifts in bacterial communities of two caribbean reef-building coral species affected by white plague disease. Isme Journal 6:502-512. 10.1038/ismej.2011.123

Carignan KS, McLean SJ, Eakins BW, Beasley L, Love MR, and Sutherland M. 2015. Digital Elevation Model of Miami, Florida: Procedures, data sources, and analysis. NOAA Technical Report. Boulder, CO: National Geophysical Data Center. p 11 pp.

Castelao R, Chant R, Glenn S, and Schofield O. 2010. The effects of tides and oscillatory winds on the subtidal inner-shelf cross-shelf circulation. Journal of Physical Oceanography 40:775-788. 10.1175/2009jpo4273.1

Clarke KR, and Warwick RM. 1994. Similarity-based testing for community pattern - The 2-way layout with no replication. Marine Biology 118:167-176. 10.1007/bf00699231

Cushman-Roisin B, and Beckers J-M. 2011. Introduction to Geophysical Fluid Dynamics: Physical and Numerical Aspects: Academic Press.

Davis KA, Lentz SJ, Pineda J, Farrar JT, Starczak VR, and Churchill JH. 2011. Observations of the thermal environment on Red Sea platform reefs: a heat budget analysis. Coral Reefs 30:25-36. 10.1007/s00338-011-0740-8

Drury C, Schopmeyer S, Goergen E, Bartels E, Nedimyer K, Johnson M, Maxwell K, Galvan V, Manfrino C, and Lirman D. 2017. Genomic patterns in Acropora cervicornis show extensive population structure and variable genetic diversity. Ecology and Evolution 7:6188-6200. 10.1002/ece3.3184

Dupont CL, Rusch DB, Yooseph S, Lombardo MJ, Richter RA, Valas R, Novotny M, YeeGreenbaum J, Selengut JD, Haft DH, Halpern AL, Lasken RS, Nealson K, Friedman R,

PeerJ reviewing PDF | (2019:03:36282:1:2:NEW 5 Jul 2019) 
606

607

608

609

610

611

612

613

614

615

616

617

618

619

620

621

622

623

624

625

626

627

628

629

630

631

632

633

634

635

636

637

638

639

640

641

642

643

644

645

646

647

648

649

650

651 and Venter JC. 2012. Genomic insights to SAR86, an abundant and uncultivated marine bacterial lineage. Isme Journal 6:1186-1199. 10.1038/ismej.2011.189

Edmunds PJ. 2010. Population biology of Porites astreoides and Diploria strigosa on a shallow Caribbean reef. Marine Ecology Progress Series 418:87-U508. 10.3354/meps08823

Feng M, Colberg F, Slawinski D, Berry O, and Babcock R. 2016a. Ocean circulation drives heterogeneous recruitments and connectivity among coral populations on the North West Shelf of Australia. Journal of Marine Systems 164:1-12. 10.1016/j.jmarsys.2016.08.001

Feng ZX, Reniers A, Haus BK, Solo-Gabriele HM, and Kelly EA. 2016b. Wave energy level and geographic setting correlate with Florida beach water quality. Marine Pollution Bulletin 104:54-60. 10.1016/j.marpolbul.2016.02.011

Gierach MM, Subrahmanyam B, and Thoppil PG. 2009. Physical and biological responses to Hurricane Katrina (2005) in a 1/25 degrees nested Gulf of Mexico HYCOM. Journal of Marine Systems 78:168-179. 10.1016/j.jmarsys.2009.05.002

Gilliam DS. 2009. Southeast Florida Coral Reef Evaluation and Monitoring Project 2008 Year 6 Final Report. Miami Beach, FL: Florida DEP Report. p 39.

Gischler E, Storz D, and Schmitt D. 2014. Sizes, shapes, and patterns of coral reefs in the Maldives, Indian Ocean: the influence of wind, storms, and precipitation on a major tropical carbonate platform. Carbonates and Evaporites 29:73-87. 10.1007/s13146-0130176-Z

Glasl B, Herndl GJ, and Frade PR. 2016. The microbiome of coral surface mucus has a key role in mediating holobiont health and survival upon disturbance. Isme Journal 10:2280-2292. 10.1038/ismej.2016.9

Gramer LJ. 2013. The dynamics of sea temperature variability on Florida's reef tract Ph.D. University of Miami Rosenstiel School of Marine and Atmospheric Studies.

Gramer LJ, and Hendee JC. 2018. Coastal turbidity on the southeast Florida shelf: Monitoring turbid water sources and fates by satellite. NOAA Technical Memorandum OARAOML-105. Miami, FL, USA: NOAA-AOML. p 46 pp.

Gramer LJ, Hendee JC, Stamates SJ, Walker BK, Walter RK, and Coleman DJ. 2018. Upwelling on the southeast Florida shelf: Summer sea temperature extremes and associated nutrient fluxes over a 17 year period. NOAA Technical Memorandum OAR-AOML-107. Miami, FL, USA: NOAA AOML. p 45 pp.

Gregr EJ, and Bodtker KM. 2007. Adaptive classification of marine ecosystems: Identifying biologically meaningful regions in the marine environment. Deep-Sea Research Part IOceanographic Research Papers 54:385-402. 10.1016/j.dsr.2006.11.004

Harborne AR, Mumby PJ, Zychaluk K, Hedley JD, and Blackwell PG. 2006. Modeling the beta diversity of coral reefs. Ecology 87:2871-2881. 10.1890/00129658(2006)87[2871:mtbdoc]2.0.co;2

Hearn CJ, Atkinson MJ, and Falter JL. 2001. A physical derivation of nutrient-uptake rates in coral reefs: effects of roughness and waves. Coral Reefs 20:347-356. 10.1007/s00338001-0185-6

Henriques IS, Alves A, Tacao M, Almeida A, Cunha A, and Correia A. 2006. Seasonal and spatial variability of free-living bacterial community composition along an estuarine gradient (Ria de Aveiro, Portugal). Estuarine Coastal and Shelf Science 68:139-148. 10.1016/j.eccs.2006.01.015

Kelly LW, Williams GJ, Barott KL, Carlson CA, Dinsdale EA, Edwards RA, Haas AF, Haynes M, Lim YW, McDole T, Nelson CE, Sala E, Sandin SA, Smith JE, Vermeij MJA, Youle

PeerJ reviewing PDF | (2019:03:36282:1:2:NEW 5 Jul 2019) 
652

653

654

655

656

657

658

659

660

661

662

663

664

665

666

667

668

669

670

671

672

673

674

675

676

677

678

679

680

681

682

683

684

685

686

687

688

689

690

691

692

693

694

695

696

697

M, and Rohwer F. 2014. Local genomic adaptation of coral reef-associated microbiomes to gradients of natural variability and anthropogenic stressors. Proceedings of the National Academy of Sciences of the United States of America 111:10227-10232. 10.1073/pnas.1403319111

Kench PS, and Brander RW. 2006. Wave processes on coral reef flats: Implications for reef geomorphology using Australian case studies. Journal of Coastal Research 22:209-223. 10.2112/05a-0016.1

Kimes NE, Van Nostrand JD, Weil E, Zhou JZ, and Morris PJ. 2010. Microbial functional structure of Montastraea faveolata, an important Caribbean reef-building coral, differs between healthy and yellow-band diseased colonies. Environmental Microbiology 12:541-556. 10.1111/j.1462-2920.2009.02113.x

Klaus JS, Janse I, Heikoop JM, Sanford RA, and Fouke BW. 2007. Coral microbial communities, zooxanthellae and mucus along gradients of seawater depth and coastal pollution. Environmental Microbiology 9:1291-1305. 10.1111/j.1462-2920.2007.01249.x

Lee BC, Fan YM, Chuang LZH, and Kao CC. 2009. Parametric Sensitivity Analysis of the WAVEWATCH III Model. Terrestrial Atmospheric and Oceanic Sciences 20:425-432. 10.3319/TAO.2008.04.25.01(Oc)

Lee STM, Davy SK, Tang SL, and Kench PS. 2017. Water flow buffers shifts in bacterial community structure in heat-stressed Acropora muricata. Scientific Reports 7:13. $10.1038 /$ srep43600

Lee TN, and Smith N. 2002. Volume transport variability through the Florida Keys tidal channels. Continental Shelf Research 22:1361-1377.

Leichter JJ, Helmuth B, and Fischer AM. 2006. Variation beneath the surface: Quantifying complex thermal environments on coral reefs in the Caribbean, Bahamas and Florida. Journal of Marine Research 64:563-588.

Leichter JJ, Stewart HL, and Miller SL. 2003. Episodic nutrient transport to Florida coral reefs. Limnology and Oceanography 48:1394-1407.

Leichter JJ, Wing SR, Miller SL, and Denny MW. 1996. Pulsed delivery of subthermocline water to Conch Reef (Florida Keys) by internal tidal bores. Limnology and Oceanography 41:1490-1501.

Lirman D, and Schopmeyer S. 2016. Ecological solutions to reef degradation: optimizing coral reef restoration in the Caribbean and Western Atlantic. Peerj 4:19. 10.7717/peerj.2597

Lirman D, Schopmeyer S, Manzello D, Gramer LJ, Precht WF, Muller-Karger F, Banks K, Barnes B, Bartels E, Bourque A, Byrne J, Donahue S, Duquesnel J, Fisher L, Gilliam D, Hendee J, Johnson M, Maxwell K, McDevitt E, Monty J, Rueda D, Ruzicka R, and Thanner S. 2011. Severe 2010 cold-water event caused unprecedented mortality to corals of the Florida reef tract and reversed previous survivorship patterns. Plos One 6:e23047. e23047 10.1371/journal.pone.0023047

Lowe RJ, and Falter JL. 2015. Oceanic Forcing of Coral Reefs. In: Carlson CA, and Giovannoni SJ, eds. Annual Review of Marine Science, Vol 7. Palo Alto: Annual Reviews, 43-66.

Lozupone C, and Knight R. 2005. UniFrac: a new phylogenetic method for comparing microbial communities. Applied and Environmental Microbiology 71:8228-8235.

10.1128/aem.71.12.8228-8235.2005

Lü XF, Ma B, Yu JB, Chang SX, Xu JM, Li YZ, Wang GM, Han GX, Bo G, and Chu XJ. 2016. Bacterial community structure and function shift along a successional series of tidal flats in the Yellow River Delta. Scientific Reports 6:10. 10.1038/srep36550 
698

699

700

701

702

703

704

705

706

707

708

709

710

711

712

713

714

715

716

717

718

719

720

721

722

723

724

725

726

727

728

729

730

731

732

733

734

735

736

737

738

739

740

741

742

743

Manzello DP, Brandt M, Smith TB, Lirman D, Hendee JC, and Nemeth RS. 2007. Hurricanes benefit bleached corals. Proceedings of the National Academy of Sciences of the United States of America 104:12035-12039. 10.1073/pnas.0701194104

McDevitt-Irwin JM, Baum JK, Garren M, and Vega Thurber RL. 2017. Responses of coralassociated bacterial communities to local and global stressors. Frontiers in Marine Science 4:262.

Monismith SG, Barkdull MK, Nunome Y, and Mitarai S. 2018. Transport Between Palau and the Eastern Coral Triangle: Larval Connectivity or Near Misses. Geophysical Research Letters 45:4974-4981. 10.1029/2018g1077493

Monismith SG, Davis KA, Shellenbarger GG, Hench JL, Nidzieko NJ, Santoro AE, Reidenbach MA, Rosman JH, Holtzman R, Martens CS, Lindquist NL, Southwell MW, and Genin A. 2010. Flow effects on benthic grazing on phytoplankton by a Caribbean reef. Limnology and Oceanography 55:1881-1892. 10.4319/lo.2010.55.5.1881

O'Connell L, Gao S, McCorquodale D, Fleisher J, and Lopez JV. 2018. Fine grained compositional analysis of Port Everglades Inlet microbiome using high throughput DNA sequencing. Peerj 6:21. 10.7717/peerj.4671

Pantos O, Bongaerts P, Dennis PG, Tyson GW, and Hoegh-Guldberg O. 2015. Habitat-specific environmental conditions primarily control the microbiomes of the coral Seriatopora hystrix. Isme Journal 9:1916-1927. 10.1038/ismej.2015.3

Park S, Ha MJ, Jung YT, Kang CH, and Yoon JH. 2016. Tenacibaculum sediminilitoris sp nov., isolated from a tidal flat. International Journal of Systematic and Evolutionary Microbiology 66:2610-2616. 10.1099/ijsem.0.001086

Pitts PA, and Smith NP. 1997. An investigation of summer upwelling across central Florida's Atlantic coast: The case for wind stress forcing. Journal of Coastal Research 13:105-110. Pootakham W, Mhuantong W, Putchim L, Yoocha T, Sonthirod C, Kongkachana W, Sangsrakru D, Naktang C, Jomchai N, Thongtham N, and Tangphatsornruang S. 2018. Dynamics of coral-associated microbiomes during a thermal bleaching event. Microbiologyopen 7. 10.1002/mbo3.604

Porter SN, Branch GM, and Sink KJ. 2017. Changes in shallow-reef community composition along environmental gradients on the East African coast. Marine Biology 164. 10.1007/s00227-017-3130-0

Robinson MD, McCarthy DJ, and Smyth GK. 2010. edgeR: a Bioconductor package for differential expression analysis of digital gene expression data. Bioinformatics 26:139140. 10.1093/bioinformatics/btp616

Roder C, Arif C, Daniels C, Weil E, and Voolstra CR. 2014. Bacterial profiling of White Plague Disease across corals and oceans indicates a conserved and distinct disease microbiome. Molecular Ecology 23:965-974. 10.1111/mec.12638

Rogers JS, Maticka SA, Chirayath V, Woodson CB, Alonso JJ, and Monismith SG. 2018. Connecting Flow over Complex Terrain to Hydrodynamic Roughness on a Coral Reef. Journal of Physical Oceanography 48:1567-1587. 10.1175/jpo-d-18-0013.1

Rogers JS, Monismith SG, Dunbar RB, and Koweek D. 2015. Field observations of wave-driven circulation over spur and groove formations on a coral reef. Journal of Geophysical Research-Oceans 120:145-160. 10.1002/2014jc010464

Rogers JS, Monismith SG, Feddersen F, and Storlazzi CD. 2013. Hydrodynamics of spur and groove formations on a coral reef. Journal of Geophysical Research-Oceans 118:30593073. 10.1002/jgrc. 20225

PeerJ reviewing PDF | (2019:03:36282:1:2:NEW 5 Jul 2019) 
744

745

746

747

748

749

750

751

752

753

754

755

756

757

758

759

760

761

762

763

764

765

766

767

768

769

770

771

772

773

774

775

776

777

778

779

780

781

782

783

784

785

786

787

788
Roik A, Rothig T, Roder C, Ziegler M, Kremb SG, and Voolstra CR. 2016. Year-Long Monitoring of Physico-Chemical and Biological Variables Provide a Comparative Baseline of Coral Reef Functioning in the Central Red Sea. Plos One 11. 10.1371/journal.pone.0163939

Salmeron R, Garcia CB, and Garcia J. 2018. Variance Inflation Factor and Condition Number in multiple linear regression. Journal of Statistical Computation and Simulation 88:23652384. 10.1080/00949655.2018.1463376

Sawstrom C, Hyndes GA, Eyre BD, Huggett MJ, Fraser MW, Lavery PS, Thomson PG, Tarquinio F, Steinberg PD, and Laverock B. 2016. Coastal connectivity and spatial subsidy from a microbial perspective. Ecology and Evolution 6:6662-6671. 10.1002/ece 3.2408

Serrano X, Baums IB, O'Reilly K, Smith TB, Jones RJ, Shearer TL, Nunes FLD, and Baker AC. 2014. Geographic differences in vertical connectivity in the Caribbean coral Montastraea cavernosa despite high levels of horizontal connectivity at shallow depths. Molecular Ecology 23:4226-4240. 10.1111/mec.12861

Serrano XM, Baums IB, Smith TB, Jones RJ, Shearer TL, and Baker AC. 2016. Long distance dispersal and vertical gene flow in the Caribbean brooding coral Porites astreoides. Scientific Reports 6:12. 10.1038/srep21619

Shedrawi G, Falter JL, Friedman KJ, Lowe RJ, Pratchett MS, Simpson CJ, Speed CW, Wilson SK, and Zhang ZL. 2017. Localised hydrodynamics influence vulnerability of coral communities to environmental disturbances. Coral Reefs 36:861-872. 10.1007/s00338017-1576-7

Siboni N, Ben-Dov E, Sivan A, and Kushmaro A. 2008. Global distribution and diversity of coral-associated Archaea and their possible role in the coral holobiont nitrogen cycle. Environmental Microbiology 10:2979-2990. 10.1111/j.1462-2920.2008.01718.x

Sinigalliano CD, Carsey TP, Enochs IC, Featherstone CM, Gidley ML, Gramer LJ, Jones PR, Rosales SM, Staley C, and Stamates SJ. 2018. Water quality and coral reef monitoring along the southeast Florida coast. NOAA Technical Memorandum OAR-AOML-47. Miami, FL, USA: NOAA-AOML. p 145 pp.

Smage SB, Brevik OJ, Duesund H, Ottem KF, Watanabe K, and Nylund A. 2016. Tenacibaculum finnmarkense sp nov., a fish pathogenic bacterium of the family Flavobacteriaceae isolated from Atlantic salmon. Antonie Van Leeuwenhoek International Journal of General and Molecular Microbiology 109:273-285. 10.1007/s10482-015-0630-0

Sponaugle S, Lee T, Kourafalou V, and Pinkard D. 2005. Florida current frontal eddies and the settlement of coral reef fishes. Limnology and Oceanography 50:1033-1048.

Staley C, Kaiser T, Gidley ML, Enochs IC, Jones PR, Goodwin KD, Sinigalliano CD, Sadowsky MJ, and Chun CL. 2017. Differential Impacts of Land-Based Sources of Pollution on the Microbiota of Southeast Florida Coral Reefs. Applied and Environmental Microbiology 83:16. 10.1128/aem.03378-16

Stammer D, Ray RD, Andersen OB, Arbic BK, Bosch W, Carrere L, Cheng Y, Chinn DS, Dushaw BD, Egbert GD, Erofeeva SY, Fok HS, Green JAM, Griffiths S, King MA, Lapin V, Lemoine FG, Luthcke SB, Lyard F, Morison J, Muller M, Padman L, Richman JG, Shriver JF, Shum CK, Taguchi E, and Yi Y. 2014. Accuracy assessment of global barotropic ocean tide models. Reviews of Geophysics 52:243-282. 10.1002/2014rg000450

PeerJ reviewing PDF | (2019:03:36282:1:2:NEW 5 Jul 2019) 
789

Sweet MJ, Brown BE, Dunne RP, Singleton I, and Bulling M. 2017. Evidence for rapid, tiderelated shifts in the microbiome of the coral Coelastrea aspera. Coral Reefs 36:815-828. 10.1007/s00338-017-1572-y

Tkachenko KS, and Soong K. 2017. Dongsha Atoll: A potential thermal refuge for reef-building corals in the South China Sea. Marine Environmental Research 127:112-125. 10.1016/j.marenvres.2017.04.003

Tolman HL. 2014. User manual and system documentation of WAVEWATCH III R version 4.07. NOAA/NWS/NCEP/MMAB Tech. Note 222.

van Oppen MJH, Bongaerts P, Frade P, Peplow L, Boyd SE, Nim HT, and Bay LK. 2018. Adaptation to reef habitats through selection on the coral animal and its associated microbiome. Molecular Ecology 27:2956-2971. 10.1111/mec.14763

Walker BK, and Gilliam DS. 2013. Determining the Extent and Characterizing Coral Reef Habitats of the Northern Latitudes of the Florida Reef Tract (Martin County). Plos One 8. 10.1371/journal.pone.0080439

Walton CJ, Hayes NK, and Gilliam DS. 2018. Impacts of a regional, multi-year, multi-species coral disease outbreak in southeast Florida. Frontiers in Marine Science 5:14. 10.3389/fmars.2018.00323

Young CN, Schopmeyer SA, and Lirman D. 2012. A review of reef restoration and coral propagation using the threatened genus Acropora in the Caribbean and Western Atlantic. Bulletin of Marine Science 88:1075-1098. 10.5343/bms.2011.1143

Zaneveld JR, Burkepile DE, Shantz AA, Pritchard CE, McMinds R, Payet JP, Welsh R, Correa AMS, Lemoine NP, Rosales S, Fuchs C, Maynard JA, and Thurber RV. 2016.

Overfishing and nutrient pollution interact with temperature to disrupt coral reefs down to microbial scales. Nature Communications 7:12. 10.1038/ncomms11833

Zhang ZL, Lowe R, Falter J, and Ivey G. 2011. A numerical model of wave- and current-driven nutrient uptake by coral reef communities. Ecological Modelling 222:1456-1470. 10.1016/j.ecolmodel.2011.01.014

Ziegler M, Roik A, Porter A, Zubier K, Mudarris MS, Ormond R, and Voolstra CR. 2016. Coral microbial community dynamics in response to anthropogenic impacts near a major city in the central Red Sea. Marine Pollution Bulletin 105:629-640. 10.1016/j.marpolbul.2015.12.045

Ziegler M, Seneca FO, Yum LK, Palumbi SR, and Voolstra CR. 2017. Bacterial community dynamics are linked to patterns of coral heat tolerance. Nature Communications 8:8. 10.1038/ncomms 14213 


\section{Table $\mathbf{1}$ (on next page)}

List of categorical variables and continuous variable medians that were correlated with coral microbiota.

Only \% coral cover and mean coral size of the overall reef were not used in the analysis. 


\begin{tabular}{|c|c|c|c|c|c|c|c|c|c|c|c|c|c|c|c|c|c|}
\hline Reef & Month & Species & $\mathbf{N}$ & $\begin{array}{l}\% \\
\text { Coral } \\
\text { cover } \\
\mathrm{cm}^{2}\end{array}$ & $\begin{array}{l}\mu \\
\text { coral } \\
\text { size } \\
\mathrm{cm}^{3}\end{array}$ & $\begin{array}{l}\% \\
\text { Coral } \\
\text { cover } \\
\text { for SS } \\
\text { and } \\
\text { PA } \\
\mathrm{cm}^{2}\end{array}$ & $\begin{array}{l}\underline{\mu} \\
\text { Coral } \\
\text { Size } \\
\text { for SS } \\
\text { and } \\
\text { PA } \\
\mathrm{cm}^{3}\end{array}$ & $\begin{array}{l}\text { Depth } \\
\text { [m] }\end{array}$ & $\begin{array}{l}\text { Sea } \\
\text { floor } \\
\text { slope }\end{array}$ & $\begin{array}{l}\text { Min. } \\
\text { dive } \\
\text { watch } \\
\text { temp } \\
{\left[{ }^{\circ} \mathrm{C}\right]}\end{array}$ & $\begin{array}{l}\text { Dist. to } \\
\text { nearest } \\
\text { Inlet } \\
\text { [km] }\end{array}$ & $\begin{array}{l}\text { Relative } \\
\text { Turbidity }\end{array}$ & $\begin{array}{l}\text { Sig. } \\
\text { Wave } \\
\text { Height } \\
{[\mathrm{m}]}\end{array}$ & $\begin{array}{l}\mathbf{M}_{\mathrm{m}} \text { tide } \\
\text { stage } \\
{[\mathrm{m}]}\end{array}$ & $\begin{array}{l}\text { Sea } \\
\text { level } \\
{[\mathrm{m}]}\end{array}$ & $\begin{array}{l}\text { Along- } \\
\text { shore } \\
\text { current } \\
{[\mathrm{m} / \mathrm{s}]}\end{array}$ & $\begin{array}{l}\text { Cross- } \\
\text { shore } \\
\text { current } \\
{[\mathrm{m} / \mathrm{s}]}\end{array}$ \\
\hline Barracuda & Mar. & PA & 2 & 1.97 & 354 & 0.209 & 130.1 & -9.76 & 0.037 & 23.2 & 2.470 & -0.068 & 0.277 & -0.0080 & -0.050 & 0.346 & -0.050 \\
\hline Barracuda & Jun. & PA & 2 & 2.01 & 343 & 0.264 & 129.75 & -9.76 & 0.037 & 28.2 & 2.470 & 0.142 & 0.180 & 0.0008 & 0.007 & 0.475 & -0.077 \\
\hline Barracuda & Sept. & PA & 2 & 1.5 & 333.8 & 0.262 & 132.73 & -9.76 & 0.037 & 29.2 & 2.470 & -0.478 & 0.074 & -0.0058 & -0.091 & 0.329 & -0.084 \\
\hline Barracuda & Mar. & SS & 4 & 1.97 & 354 & 0.209 & 156.33 & -10.07 & 0.031 & 23.4 & 2.029 & -0.060 & 0.254 & -0.0080 & -0.050 & 0.341 & -0.045 \\
\hline Barracuda & Jun. & SS & 2 & 2.01 & 343 & 0.264 & 129.75 & -10.15 & 0.031 & 28.2 & 2.317 & 0.143 & 0.176 & 0.0008 & 0.007 & 0.470 & -0.081 \\
\hline Barracuda & Sept. & SS & 4 & 1.5 & 333.8 & 0.262 & 127.25 & -10.07 & 0.031 & 29 & 2.029 & -0.383 & 0.068 & -0.0058 & -0.091 & 0.325 & -0.072 \\
\hline Emerald & Mar. & PA & 1 & 1.33 & 261.2 & 0.169 & 232.33 & -7.25 & 0.024 & 24 & 10.183 & -0.075 & 0.258 & -0.0052 & -0.075 & 0.445 & 0.036 \\
\hline Emerald & Jun. & PA & 1 & 1.28 & 209.5 & 0.193 & 93.75 & -7.25 & 0.024 & 28 & 10.183 & -0.426 & 0.182 & 0.0016 & 0.064 & 0.614 & 0.040 \\
\hline Emerald & Sept. & PA & 3 & 1.17 & 198.8 & 0.205 & 230.5 & -8.48 & 0.022 & 29.2 & 10.528 & -0.379 & 0.225 & 0.0003 & 0.155 & 0.377 & 0.031 \\
\hline Emerald & Mar. & SS & 1 & 1.33 & 261.2 & 0.169 & 101.86 & -7.25 & 0.024 & 24 & 10.183 & -0.075 & 0.258 & -0.0052 & -0.075 & 0.445 & 0.036 \\
\hline Emerald & Jun. & SS & 1 & 1.28 & 209.5 & 0.193 & 93.75 & -7.25 & 0.024 & 28 & 10.183 & -0.426 & 0.182 & 0.0016 & 0.064 & 0.614 & 0.040 \\
\hline Emerald & Sept. & SS & 3 & 1.17 & 198.8 & 0.205 & 87.5 & -8.48 & 0.022 & 29.2 & 10.528 & -0.379 & 0.225 & \begin{tabular}{|l|l|}
0.0003 \\
\end{tabular} & 0.155 & 0.377 & 0.031 \\
\hline $\begin{array}{l}\text { Oakland } \\
\text { Ridge }\end{array}$ & Mar. & PA & 3 & 2.34 & 186.2 & 0.463 & 223.5 & -8.59 & 0.048 & 22.4 & 7.206 & -0.089 & 0.255 & -0.0076 & -0.049 & 0.259 & -0.001 \\
\hline $\begin{array}{l}\text { Oakland } \\
\text { Ridge }\end{array}$ & Jun. & PA & 1 & 2.37 & 199.9 & 0.519 & 161.71 & -8.67 & 0.048 & 28 & 7.206 & 0.110 & 0.143 & -0.0050 & -0.104 & 0.302 & 0.026 \\
\hline $\begin{array}{l}\text { Oakland } \\
\text { Ridge }\end{array}$ & Sept. & PA & 3 & 2.31 & 193.8 & 0.519 & 219.67 & -8.59 & 0.048 & 28.8 & 7.206 & -0.141 & 0.067 & -0.0043 & -0.088 & 0.245 & 0.023 \\
\hline $\begin{array}{l}\text { Oakland } \\
\text { Ridge }\end{array}$ & Mar. & SS & 3 & 2.34 & 186.2 & 0.463 & 171.07 & -8.59 & 0.048 & 22.4 & 7.206 & -0.089 & 0.255 & -0.0076 & -0.049 & 0.259 & -0.001 \\
\hline $\begin{array}{l}\text { Oakland } \\
\text { Ridge }\end{array}$ & Sept. & SS & 3 & 2.31 & 193.8 & 0.519 & 161.71 & -8.59 & 0.048 & 28.8 & 7.206 & -0.141 & 0.067 & -0.0043 & -0.088 & 0.245 & 0.023 \\
\hline Pillars & Mar. & PA & 2 & 1.36 & 244.5 & 0.192 & 126.5 & -10.31 & 0.014 & 23.2 & 4.784 & -0.128 & 0.310 & -0.0065 & -0.062 & 0.310 & -0.024 \\
\hline Pillars & Jun. & PA & 2 & 1.03 & 300.9 & 0.134 & 162 & -10.31 & 0.014 & 28 & 4.784 & -0.164 & 0.183 & 0.0021 & 0.075 & 0.406 & -0.021 \\
\hline Pillars & Sept. & PA & 2 & 0.97 & 290.3 & 0.149 & 101 & -10.31 & 0.014 & 30.2 & 4.784 & -0.089 & 0.253 & 0.0005 & 0.155 & 0.238 & 0.000 \\
\hline Pillars & Mar. & SS & 4 & 1.36 & 244.5 & 0.192 & 269 & -10.92 & 0.015 & 23.8 & 4.531 & -0.121 & 0.327 & -0.0065 & -0.062 & 0.310 & -0.006 \\
\hline Pillars & Jun. & SS & 2 & 1.03 & 300.9 & 0.134 & 162 & -11.49 & 0.015 & 28 & 4.412 & -0.172 & 0.201 & 0.0021 & 0.075 & 0.405 & 0.007 \\
\hline Pillars & Sept. & SS & 4 & 0.97 & 290.3 & 0.149 & 205.6 & -10.92 & 0.015 & 30 & 4.531 & -0.088 & 0.267 & 0.0005 & 0.155 & 0.238 & 0.013 \\
\hline
\end{tabular}

$1 \mathrm{~N}$ is the number of replicates (distinct coral heads) of that host species sampled at that reef in that month. SS =Siderastrea siderea and

$2 \mathrm{PA}=$ Porites astreoides. 


\section{Figure 1}

Geography of the study region.

(A) Wider geography of the Florida reef tract, showing boundaries of southern Florida counties. Sampling sites are shown as colored markers offshore of Miami-Dade and Broward counties. Grey contours show the 10, 30, and 250 m isobath. (B) High resolution bathymetry of the sampling region, showing southeast Florida's coastline in heavy black, sampling sites as colored markers, and isobaths as color contours at $3 \mathrm{~m}$ depth intervals down to $30 \mathrm{~m}$, followed by the 40,50 , and $60 \mathrm{~m}$ isobaths offshore. The high resolution of this bathymetry highlights the linear, north-south features of south Florida reefs, as well as major man-made channels cut across them: Port of Miami at 25.76, Haulover at 25.90, and Port Everglades at $26.09{ }^{\circ} \mathrm{N}$ latitude.

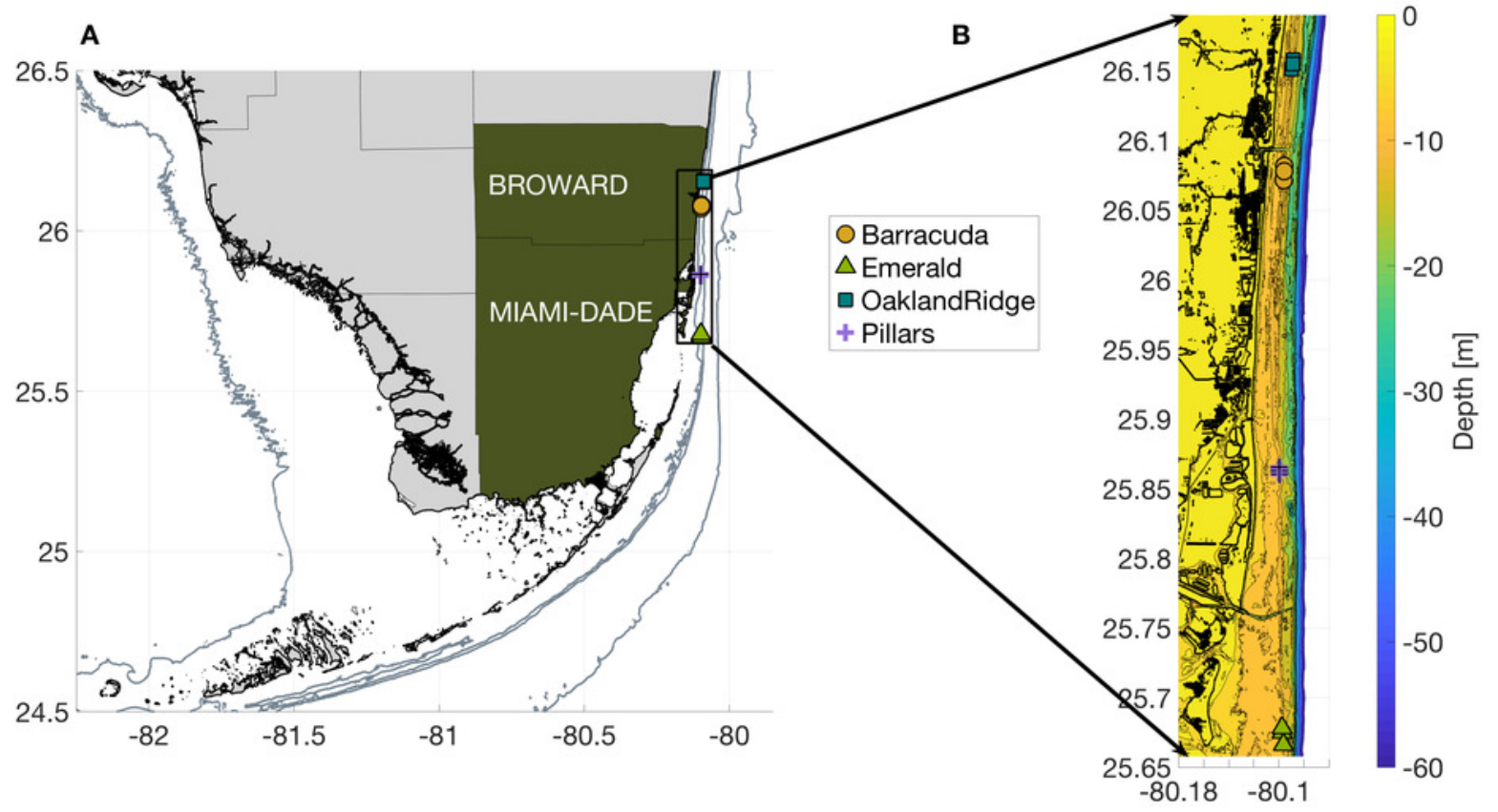




\section{Figure 2}

Physical habitat spatial fields, with time-averaged across the full weeks surrounding each sampling period.

In $(A, D)$ March, $(B, E)$ June, and $(C, F)$ September. Panels $(A-C)$ show normalized relative turbidity from satellite, and (D-F) show alongshore current $\left[\mathrm{m} \mathrm{s}^{-1}\right]$ from GoM HYCOM. In (D-F), alongshore current speed $(v)$ is shown as colored contours, and overall current direction is shown as scaled black arrows at the native model resolution. Locations of the twelve individual coral sampling sites are shown with markers, colored by reef name. 

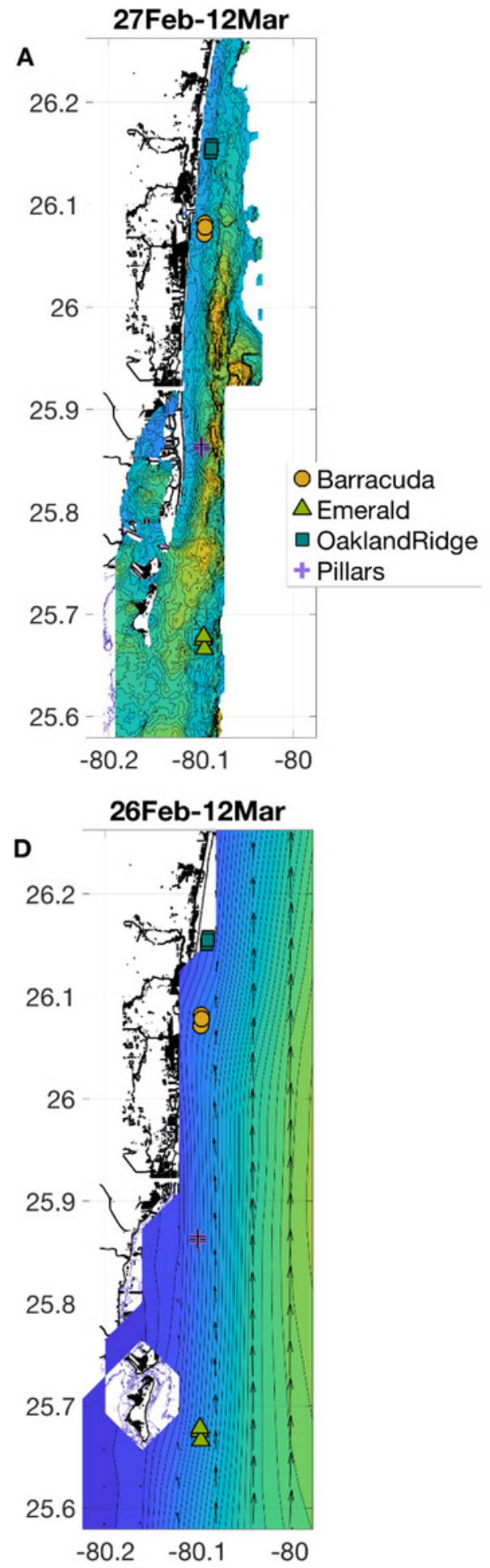

B

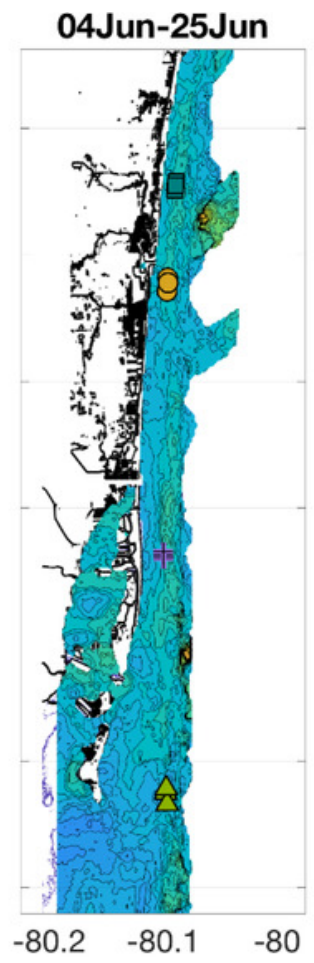

E

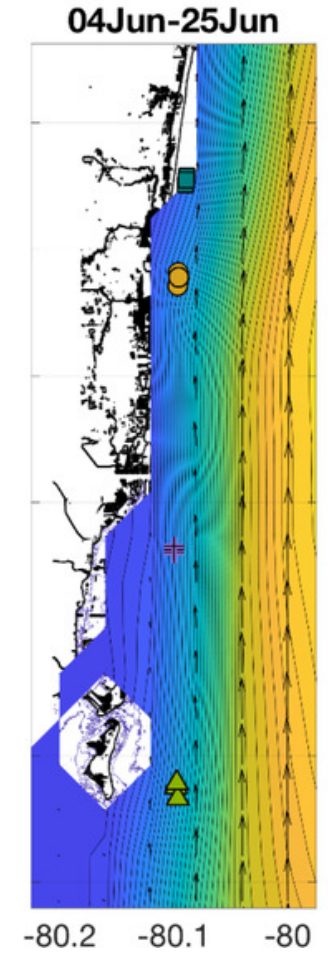

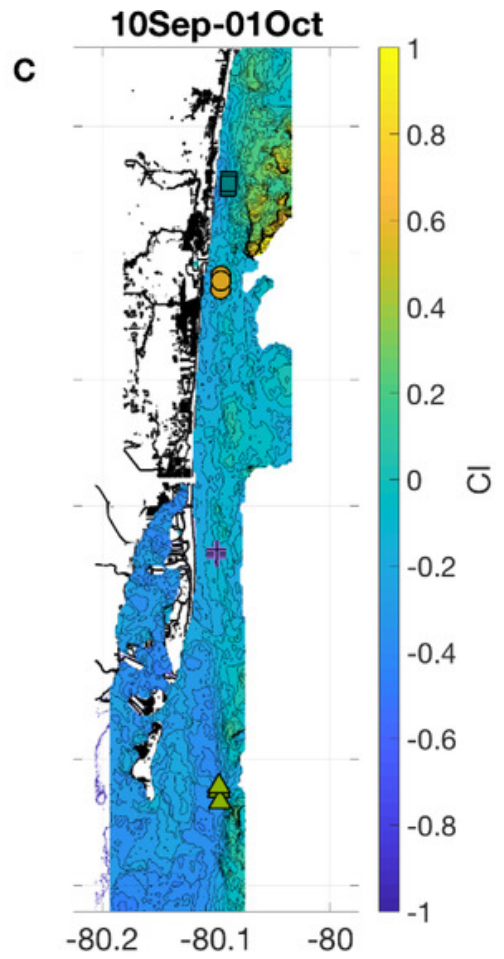

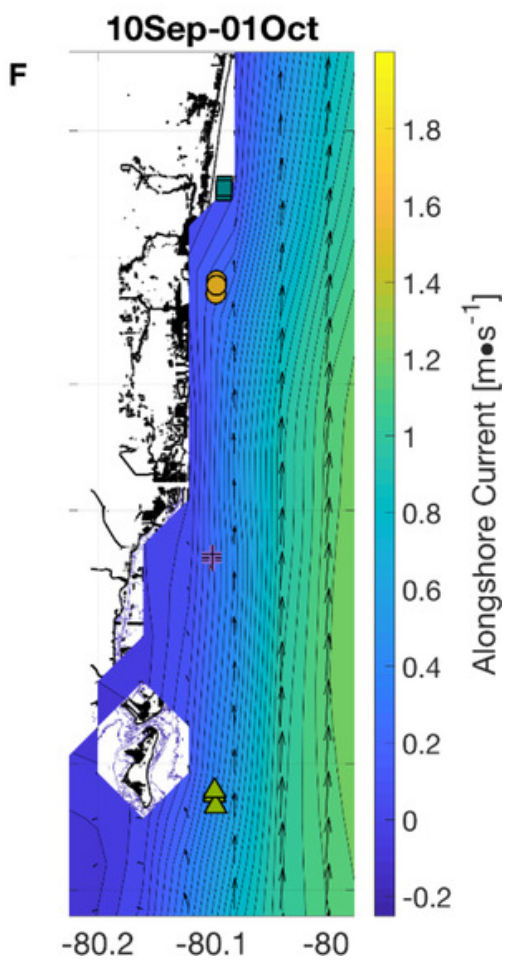




\section{Figure 3}

Physical habitat time series for 2015 at four reefs.

Reefs are marked by different shapes and dates of sampling are shown as colored markers:

(A) per-dive minimum measured sea temperature $\left[{ }^{\circ} \mathrm{C}\right]$ from divers, and for comparison, from in situ moorings inshore of (black line, at $7 \mathrm{~m}$ depth) and offshore of (gray line, at $26 \mathrm{~m}$ depth) the reef lines, as well as from a dockside station (dark red line, depth about $2 \mathrm{~m}$ ) approximately $10 \mathrm{~km}$ inshore. (B) The $14 \mathrm{~d}$ centered moving average of significant wave height [m] from NOAA WaveWatch III surface wave model, at the grid point where each sample was gathered. (C) The $14 \mathrm{~d}$ centered moving average of normalized relative turbidity from satellite ocean color at the pixel where each sample was gathered. (D) The $14 \mathrm{~d}$ centered moving average of alongshore current $\left[\mathrm{m} \mathrm{s}^{-1}\right]$ from GoM HYCOM linearly interpolated to the location where each sample was gathered. The Low-pass (40-hour) filtered time series (40HLP) of measured depth-averaged ocean currents are shown in black for moorings immediately inshore ( $7 \mathrm{~m}$ depth, solid) and offshore (26 m depth, dashed) of the major reef line. 

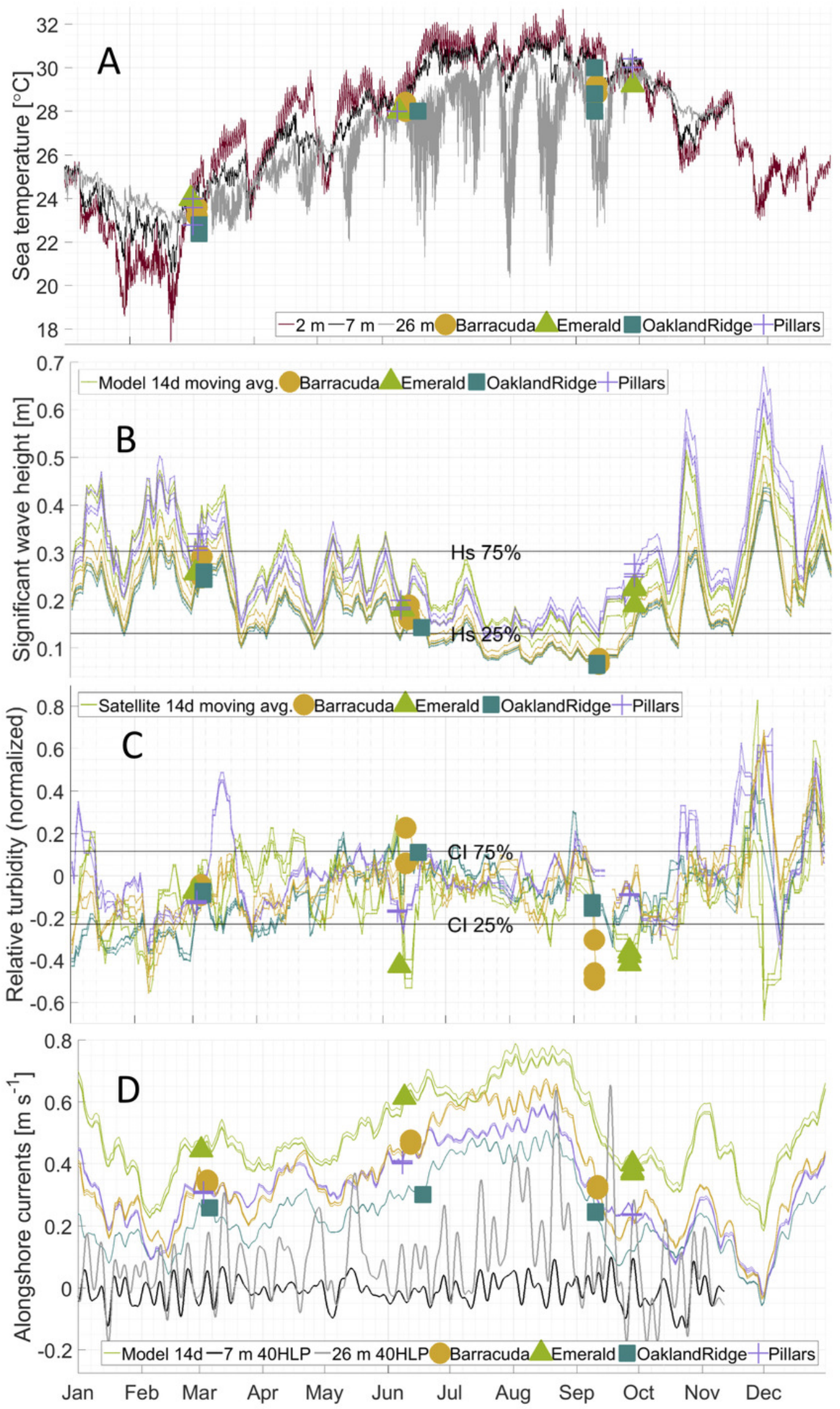
Figure 4

Relative abundance of microbial communities of Siderastrea siderea and Porites astreoides tissue from four Southeast Florida reefs.

Stacked bar colors indicate different genera and the relative abundance of each genus of the most abundant ( $>0.05 \%$ ) ASVs. The figure is grouped by reef site, the month of sampling, and the host-species. 


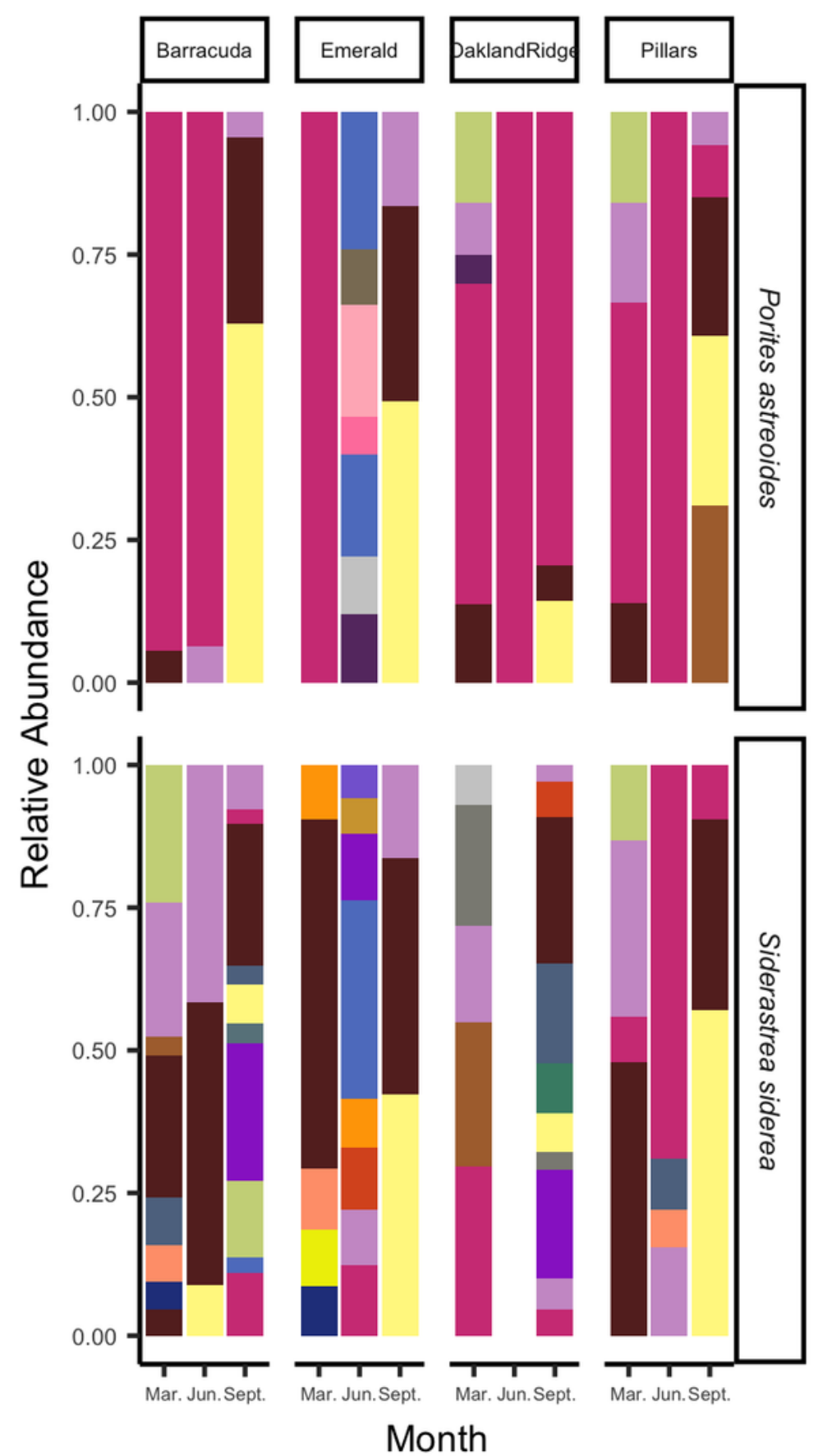

Genus

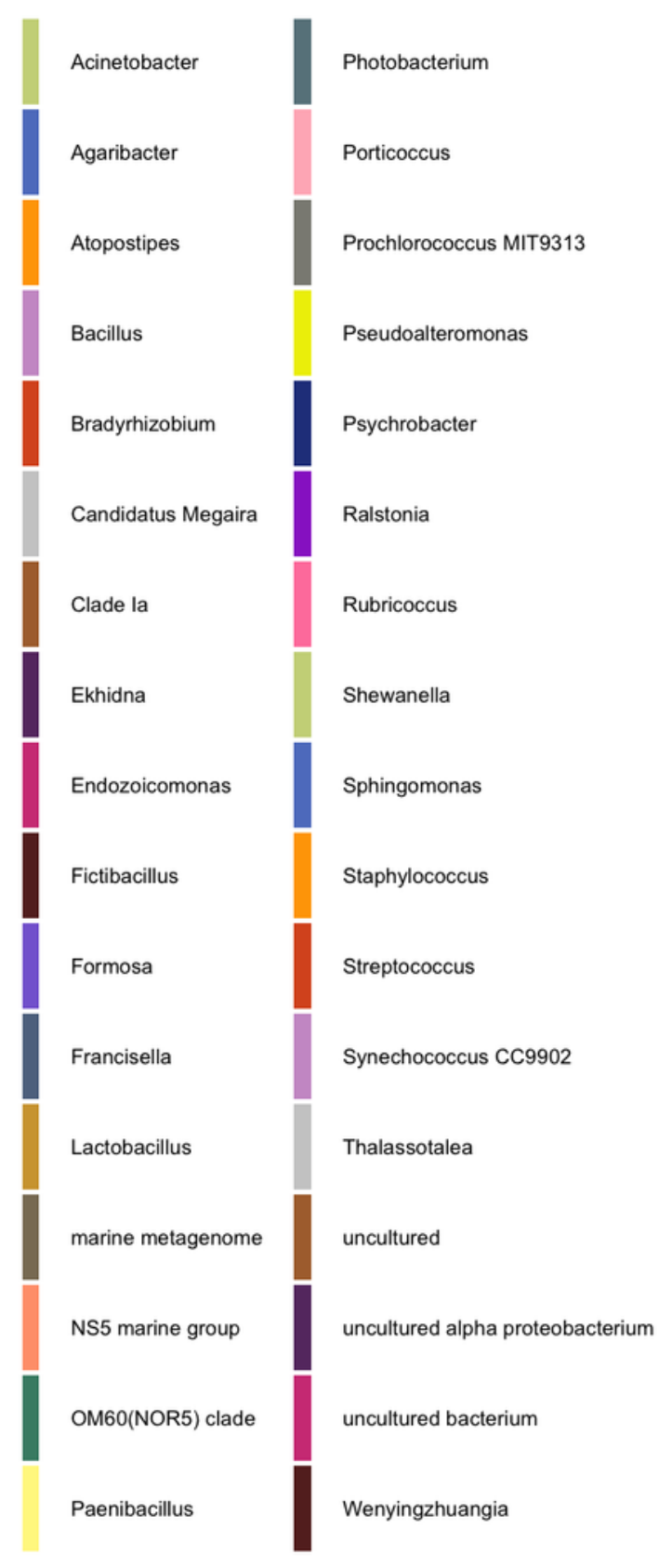




\section{Figure 5}

Microbial alpha-diversity from coral species Siderastrea siderea and Porites astreoides from four Southeast Florida reefs.

Samples are colored by month and shaped by the reef name. The blue line represents the linear regression best fit between the habitat variable ( $x$ axis) and the diversity metric ( $y$ axis); grey shadow around the blue line is the $95 \%$ confidence interval. The first column plots Shannon diversity vs. physical habitat variables that were found to be significant to it $(p<$ 0.05) (A) alongshore currents $\left[\mathrm{m} \mathrm{s}^{-1}\right]^{\prime}(\mathrm{B})$ tide $[\mathrm{m}]$, and $(\mathrm{C})$ temperature $\left[{ }^{\circ} \mathrm{C}\right]$. The second column of plots show species evenness of habitat vs. variables that were significant $(p<$ $0.05)(D)$ sea-level anomaly $[\mathrm{m}],(\mathrm{E})$ tide $[\mathrm{m}]$, and $(\mathrm{F})$ temperature $\left[{ }^{\circ} \mathrm{C}\right]$. 


\section{Month}

- Jun.

- Mar.

- Sept.

\section{Location}

- Barracuda

$\Delta \quad$ Emerald

- OaklandRidge

$+\quad$ Pillars
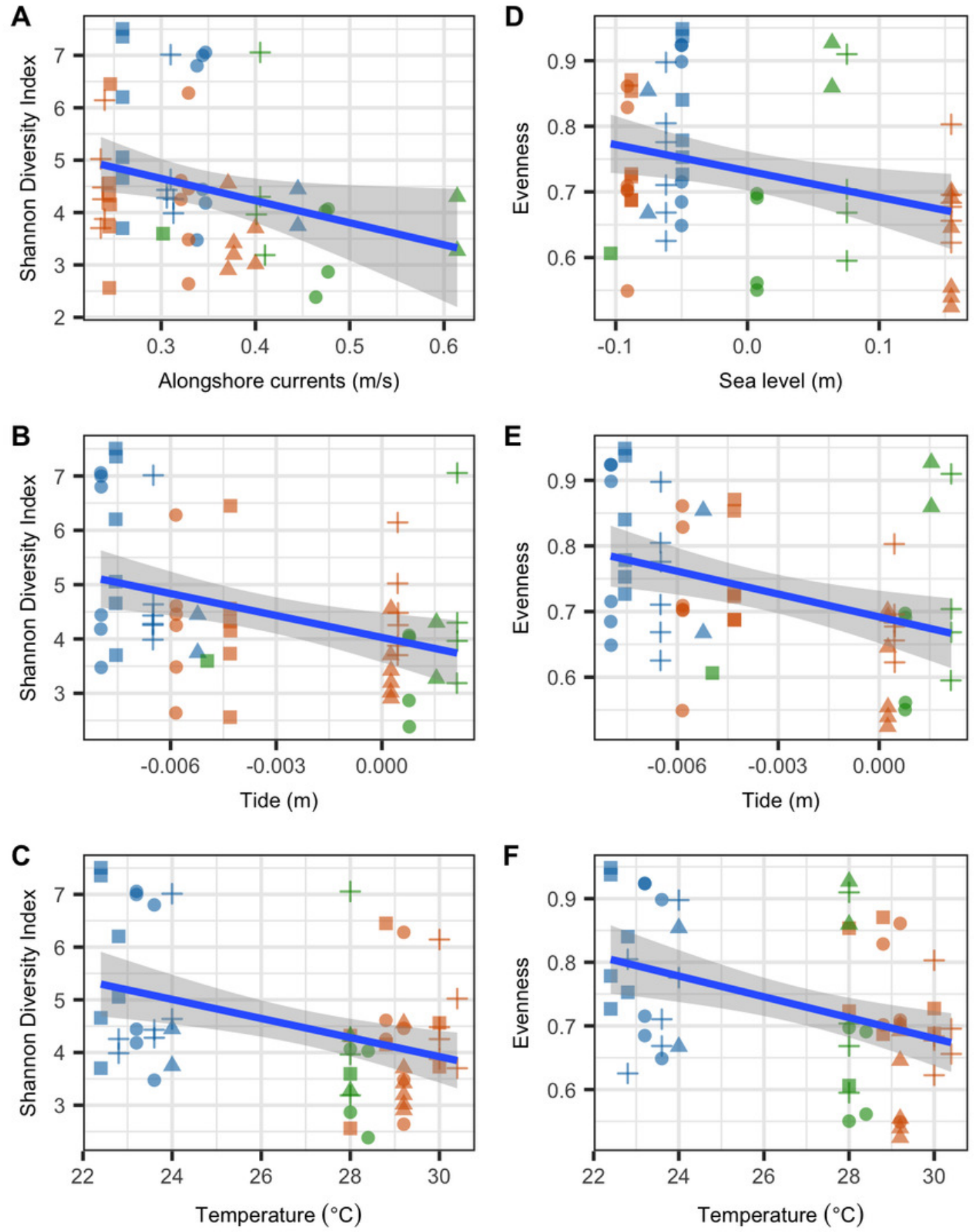


\section{Figure 6}

Microbial beta-diversity of coral Siderastrea siderea (SS) and Porites astreoides (PA) tissue from four Southeast Florida reefs.

(A) Principal coordinate analysis (PCOA) with a weighted UniFrac distance, colored by coral host-species, labeled by the month of collections and shapes are based on reef location. (B) Constrained correspondence analysis (CCA) with a Bray-Curtis statistic for microbial compositional dissimilarity. The microbiome correspondence analysis was constrained by temperature $\left[{ }^{\circ} \mathrm{C}\right]$, alongshore currents $\left[\mathrm{m} \mathrm{s}^{-1}\right]$, significant wave height $[\mathrm{m}]$, and relative turbidity (normalized). Each sample is colored by month of collection, and shapes are based on reef location.
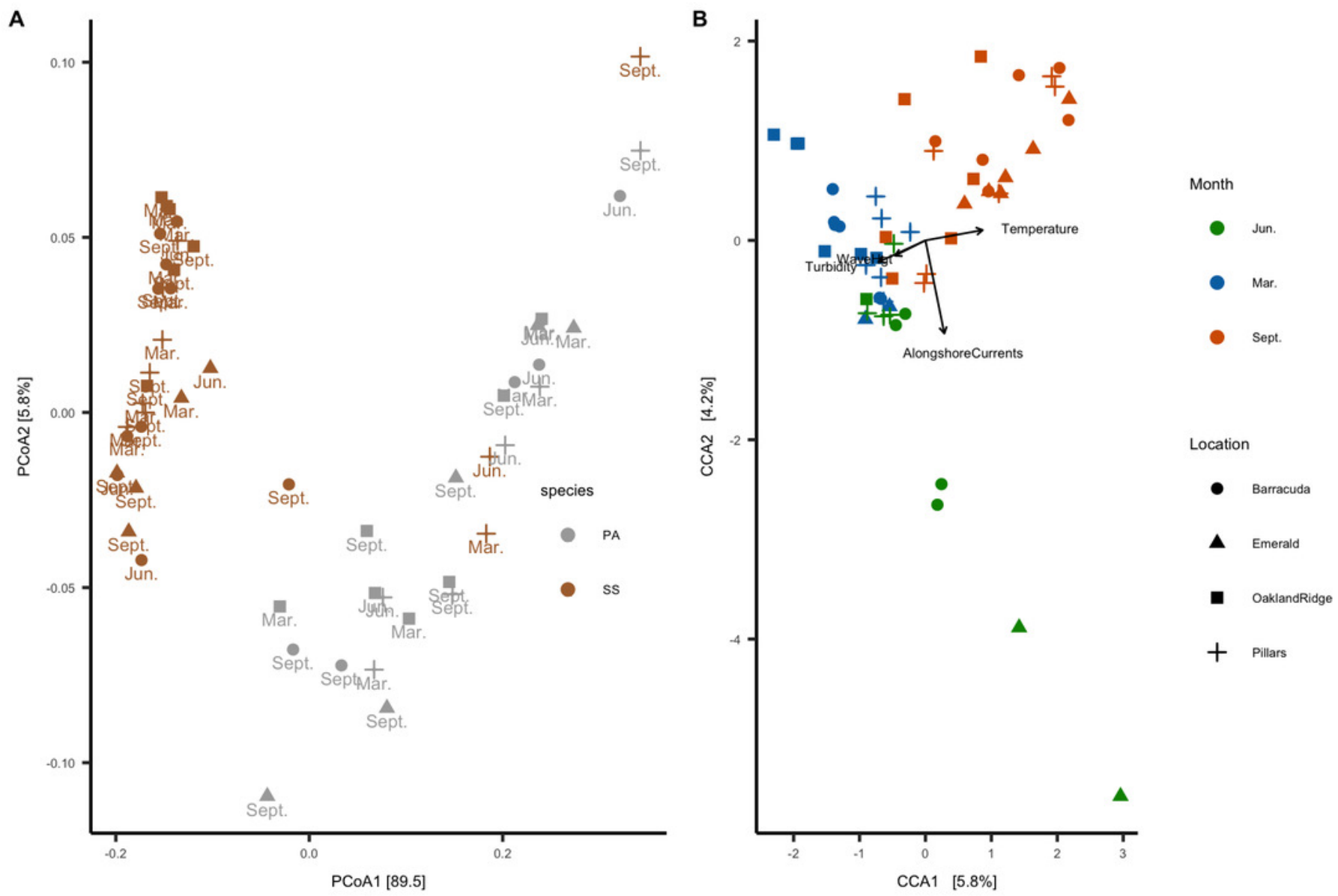


\section{Figure 7}

Microbial taxa that correlated with physical habitat variables in Southeast Florida reefs.

Samples are colored by microbial order. The colored line represents the linear regression fit between the habitat variable ( $x$ axis) and the microbe's relative abundance (y axis); grey shadow around the line is the $95 \%$ confidence interval. Plots show microbial taxa vs. physical habitat variables that were found to be significantly correlated to $\left(p<0.05, R^{2}>0.2\right)$ (A) significant wave height $[\mathrm{m}]$ and $(\mathrm{B})$ temperature $\left[{ }^{\circ} \mathrm{C}\right]$. 
A

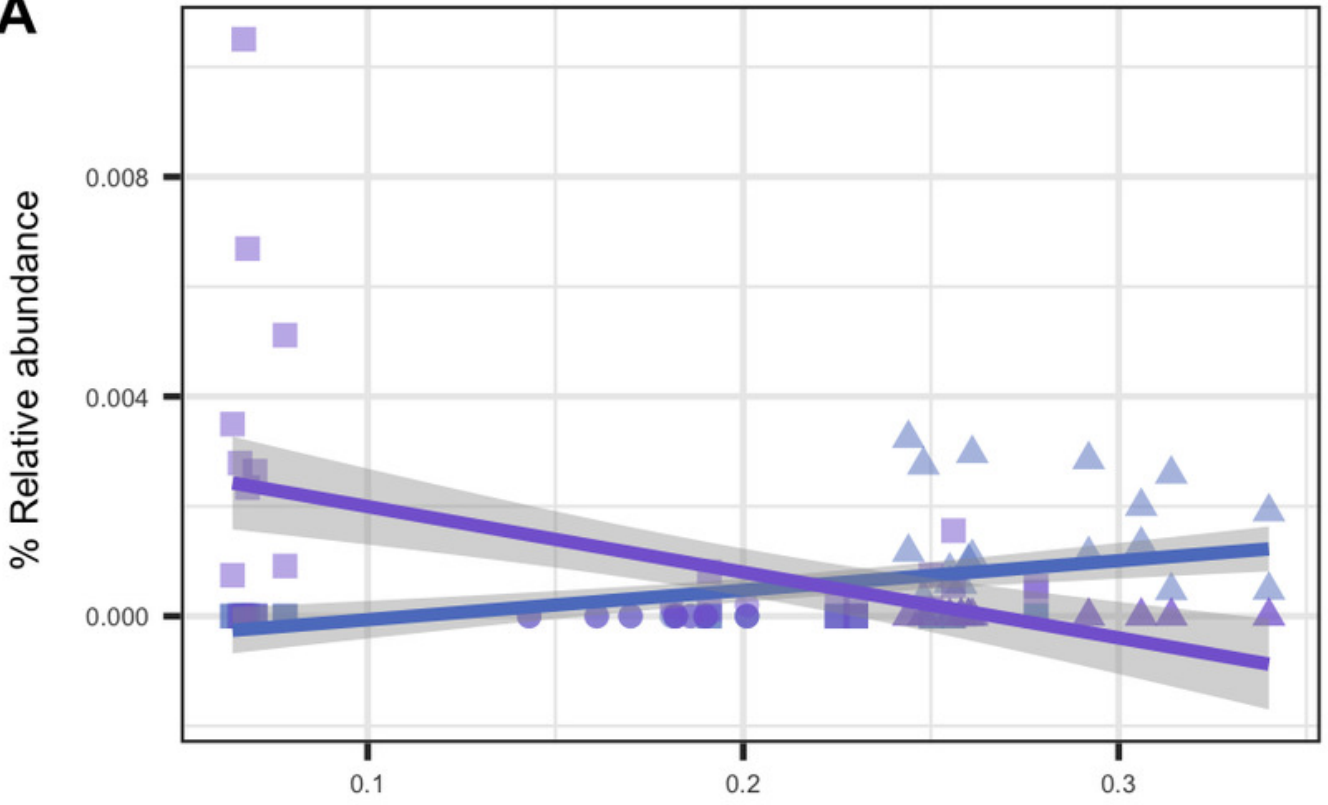

Significant wave height $(\mathrm{m})$

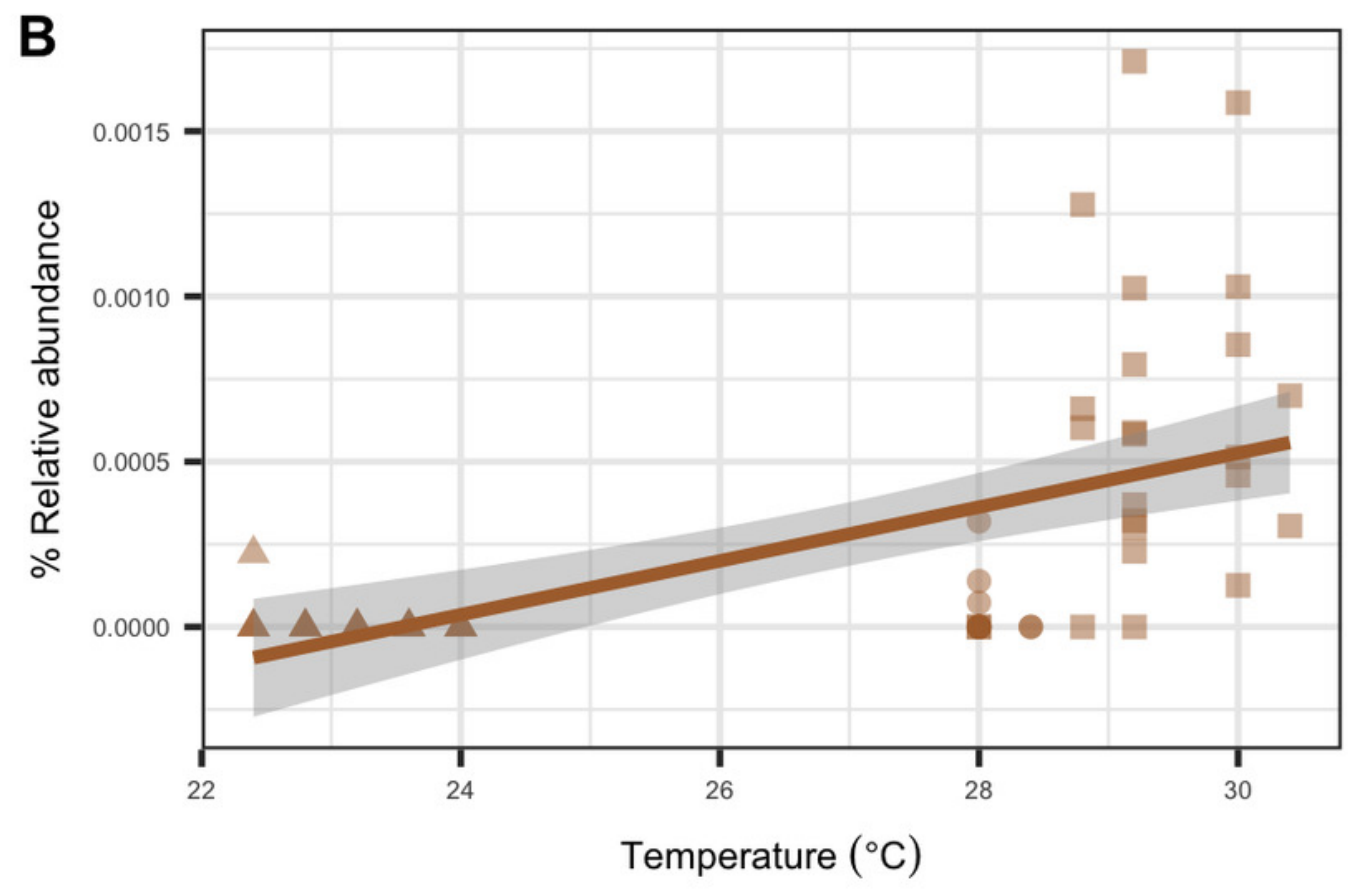

Month

Jun.

- Mar.

- Sept.

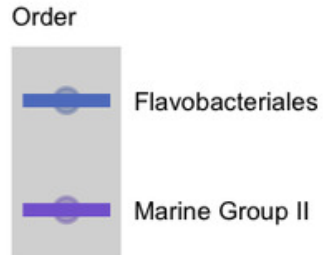

Order

SAR86 clade 